WP 04_14

\author{
Leonardo Becchetti \\ University of Rome Tor Vergata, Italy
}

Rocco Ciciretti

University of Rome Tor Vergata, Italy

The Rimini Centre for Economic Analysis (RCEA), Italy

Ambrogio Dalo

University of Rome Tor Vergata, Italy

Stefano Herzel

University of Rome Tor Vergata, Italy

\title{
SOCIALLY RESPONSIBLE AND CONVENTIONAL INVESTMENT FUNDS: Performance Comparison and THE GLOBAL FinANCIAL CRISIS
}

Copyright belongs to the author. Small sections of the text, not exceeding three paragraphs, can be used provided proper acknowledgement is given.

The Rimini Centre for Economic Analysis (RCEA) was established in March 2007. RCEA is a private, nonprofit organization dedicated to independent research in Applied and Theoretical Economics and related fields. RCEA organizes seminars and workshops, sponsors a general interest journal The Review of Economic Analysis, and organizes a biennial conference: The Rimini Conference in Economics and Finance (RCEF) . The RCEA has a Canadian branch: The Rimini Centre for Economic Analysis in Canada (RCEACanada). Scientific work contributed by the RCEA Scholars is published in the RCEA Working Papers and Professional Report series.

The views expressed in this paper are those of the authors. No responsibility for them should be attributed to the Rimini Centre for Economic Analysis. 


\title{
Socially Responsible and Conventional Investment Funds: Performance Comparison and the Global Financial Crisis*
}

\author{
Leonardo Becchettił, Rocco Ciciretti ${ }^{\ddagger}$ Ambrogio Daloई, and Stefano Herzel ${ }^{\Uparrow}$
}

February 7, 2014

\begin{abstract}
We investigate the performance of Socially Responsible Funds (SRFs) and Conventional Funds (CFs) in different market segments during the 1992-2012 period. From an unbalanced sample of more that 22,000 funds, we define a matched sample using a beta-distance measure to match any SRF with the "nearest neighbor" CF in terms of risk factors. Using this novel matching approach and a recursive analysis, we identify several switch points in the lead/lag relationship between the two investment styles over time in different market segments (geographical area and size). A relevant finding of our analysis is that SRFs played an "insurance role" outperforming CFs during the 2007 global financial crisis.
\end{abstract}

Keywords: Socially Responsible Investment Fund; Jensen's Alpha; Global Financial Crisis. JEL Classification Numbers: D84; E44; F30; G17; C53.

${ }^{*}$ The authors thank Marco Nicolosi, Annalisa Fabretti, and Alessandra Federici for useful comments during the preliminary draft. A SIRP (funded by MISTRA) grant is acknowledged by Rocco Ciciretti and Stefano Herzel. Morningstar Italia is acknowledged for data availability. All remaining errors belong to the authors. The usual disclaimers apply.

${ }^{\dagger}$ Department of Law, Economics and Institutions, University of Roma Tor Vergata. e-mail: leonardo.becchetti@uniroma2.it

${ }^{\ddagger}$ Department of Economics and Finance, University of Roma Tor Vergata and RCEA-Rimini. Corresponding address: Via Columbia 2, 00133 Roma-Italia. Phone +39-06-72595929. Fax +39-06-2040219. e-mail: rocco.ciciretti@uniroma2.it

${ }^{\S}$ Department of Economics and Finance, University of Roma Tor Vergata. e-mail: ambrogio.dalo@uniroma2.it

`Department of Economics and Finance, University of Roma Tor Vergata. e-mail: stefano.herzel@uniroma2.it 


\section{Introduction}

The progressive emergence of corporate social responsibility is increasing the interest around the relative performance of socially responsible investment funds (SRFs) versus conventional investment funds (CFs). In globally integrated markets, companies have started to operate at world level well before the formation of a set of global rules and institutions addressing market failures or negative externalities at this increased scale of operation. As a consequence, the public opinion is increasingly demanding companies to behave in a socially and environmentally responsible way. Corporate social responsibility (CSR) may therefore be considered as involving those kinds of actions by which companies go beyond what required by the laws of the country in which they operate. ${ }^{1}$ From another perspective CSR has been defined as a move from the goal of profit maximization to the broader concept of satisfaction of the interests of a wider set of stakeholders including customers, employees and communities living in the geographical area in which the company operates. Strong incentives for CSR are provided by the growth of socially responsible investment. The Report on Socially Responsible Investing Trends in the United States - Foundation (2010) - documents that 2.71 trillion dollars were invested in SRFs in 2010, corresponding to a share of around 11 per cent of total assets under management in the US. In 2011 the amount rose to 3.74 trillion dollars (the combined value of GDP of Brazil and Canada).

From a theoretical point of view managers of SRFs incur in three additional costs with respect to conventional fund managers. The first cost is related to the acquisition of the specific CSR information on investable stocks which is not a matter of interest for conventional fund managers. $^{2}$ The second is the cost of missed diversification opportunities. When using negative screening, SRF managers introduce an additional constraint in their optimal portfolio variance minimization problem by forcing to zero the share invested in those stocks which are ruled out by their CSR based selection criteria. This implies that their efficient portfolio frontier is flatter than that of the conventional fund managers - i.e. for a given level of variance the expected return is lower - Barnett and Salomon (2006), Renneboog et al. (2008a), and Renneboog et al. (2008b). Geczy et al. (2005) calculate that the SRI constraint implies a cost ranging from 5 to 10 basis points per month. It is however possible to show that such diversification cost tends to zero when the universe of investable stocks is large enough, and the negative covariance between excluded and included stocks is negligible when negative screens are not too severe - Derwall et al. (2011). In this respect Herzel et al. (2012) calculate the efficient frontier on an investment

\footnotetext{
${ }^{1}$ This is the concept of the Green Paper of the Commission (2001) which defines corporate social responsibility as "a concept whereby companies integrate social and environmental concerns in their business operations and in their interaction with their stakeholders on a voluntary basis".

${ }^{2}$ As is well known this information is retrievable from several rating agencies such as KLD, EIRIS, VIGEO which calculate and update scores of different companies on the relevant CSR domains (environment, employees, human rights, product quality, etc.).
} 
set containing the components of the S\&P500 index from 1993 to 2008, finding that socially responsible screening gives rise to a negligible loss in terms of Sharpe ratios. Their spanning test shows that the ex-post differences between the two frontiers are significant only in the case of screening based on the Environmental dimension when short selling is not allowed. The third additional cost for socially responsible investment funds is a timing cost arising if SRF managers are forced by fund rules to sell the stock of a company which modifies its behavior and looses its SR characteristics. This event may lead the fund manager to perform an action equivalent to a liquidity constrained sale, forcing her/him to a suboptimal transaction when the stock of that company has good return perspectives - Becchetti et al. (2012).

In spite of these three potential additional costs, the empirical literature comparing the performance of socially responsible and conventional funds finds mixed results. The adopted methodologies vary from one to multi-factor models and the reference group of CFs is either randomly selected or includes all available funds. In order to have a clear cut test on the superior performance of one investment style over the other, in most studies returns of individual SRFs and CFs are equally weighted, averaged in two different superfunds and a difference portfolio is calculated by subtracting monthly returns of the SRF from the CF superfund. Returns of the difference portfolio are then regressed on one or multiple risk factors to test the significance of the Jensen's alpha - Jensen (1968) - in order to compare fund manager performances under the two investment styles. By using this approach, Bauer et al. (2005) find no evidence of a significant difference between SRFs and CFs returns after controlling for common factors in the 1990-2001 period and document a learning effect in SRFs which significantly improve their performance in the 1998-2001 sub-period. Renneboog et al. (2007) find that SRFs display returns which are not significantly different from those of CFs in the US and UK, while they underperform CFs in Europe and Asia. Nofsinger and Varma (2012) find that SRFs outperform CFs in the global financial crisis concluding that they can be an optimal choice for investors who want to protect themselves from downside risk. Evidence of a missed diversification cost for SRFs is documented by Bauer et al. (2006) and Bauer et al. (2005) who find that international SRFs in the UK and US do not perform better than domestic SRFs.

Some recent evidence however documents that the performance of SRFs depends on the type of adopted investment strategy (an information which is not always available). As is well known, the ethical constraint imposed by negative screens may become particularly costly in terms of diversification if it rules out entire industries. This is why an alternative "best-in-class" (BIC) approach is often developed by selecting in each industry top CSR companies (even when top companies in the industry do not reach minimum CSR standards) in order to have a welldiversified portfolio at industry level. Kempf and Osthoff (2007) document that BIC strategies outperform benchmarks much more than non-BIC CSR strategies. They also show that SRFs specialized in community and employee CSR domains tend to outperform benchmarks, while 
this is not the case for those specialized in the human right domain. ${ }^{3}$ A common result in the literature is that SRFs and CFs have different exposure to risk factors - Geczy et al. (2005), Schroder (2004), and Gregory et al. (1997) - and that, in general, SRFs are more exposed to the small size risk factor and tend to be more growth-oriented while less value-oriented.

Our paper aims to contribute to the existing literature by investigating the performance of SRFs and CFs in the 1990-2012 time spell including the global financial crisis. We compare the relative performance of portfolio managers with different approaches - one-factor and multifactor models including Fama and French (1993), Fama and French (1996), Carhart (1996), and Bollen and Busse (2001) risk factors. From an unbalanced sample of more that 22,000 funds, we define a balanced sample using a beta-distance measure to match a SRF with the closest $\mathrm{CF}$ in terms of risk factors.

Using this new approach and a recursive analysis we i) do not find a clear cut dominance of one investment style over the other identifying several switch points in the lead/lag relationship between the two investment styles over time in different market segments, ii) document that SRFs played an "insurance role" outperforming CFs during the 2007 global financial crisis (while not in the 2001 dotcom crisis), and iii) find no evidence of a missed diversification constraint in the SRF segment since global SRFs do not outperform SRFs investing in limited geographical or size segments unless we delimit the universe of investable funds to small/medium caps.

A possible interpretation of our findings is that the three extra costs in terms of SRF management strategies do not hit much or are compensated by the potential benefits that CSR may bring to corporate profitability - minimisation of conflicts with stakeholders, leadership in environmental innovation, higher demand from socially and environmentally concerned consumers, positive effects on workers productivity, see Becchetti et al. (2013).

The paper is organized in five Sections (including Introduction and Conclusions). In the next Section, we describe our database and the methodology adopted. In Section 3, we discuss results on the comparative performance between the two investment styles from standard multi-factor models. In Section 4, we present and discuss findings from the beta-distance "nearest neighbor" approach comparing pairs of SRF and conventional investment funds based on proximity in terms of risk factors. Section 5 provides concluding remarks.

\footnotetext{
${ }^{3}$ The positive performance in the employee domain is consistent with findings from Edmans (2011) documenting that top companies in terms of employee satisfaction earn a 2.1\% excess return per year over the 1984-2009 period.
} 


\section{$2 \quad$ Data and Descriptive Statistics}

Our dataset is composed by the universe of the monthly equity investment fund returns available in the Morningstar database for the time period going from January 1992 to April 2012. Our sample period includes two financial crises according to the FRED Economic Data definition of the St. Louis Federal Reserve (the first from March 2001 to November 2001 and the second from December 2007 to June 2009). The selected sample includes 1,213 unique (selfdefined) SRFs, and 21,860 unique (self-defined) CFs in the sample period. We include dead funds in our sample in order to avoid survivorship bias. ${ }^{4}$ A first interesting piece of evidence is that during our sample period both SRFs and CFs grow significantly in number, with the growth being stronger for SRFs after the second (global) financial crisis (Figure 1, Panel A). In Panels B and C (Figure 1), we document how this result is the combination of different fund creation and destruction patterns within the two investment style groups.

\section{Insert Figure 1 About Here.}

In order to compare investment fund performance in different market segments, we use a standard taxonomy including four geographical areas of investment (Global, North America, Europe, Asia/Pacific ex Japan and China) and two investment size classes (Large Cap, and Middle/Small Cap companies). ${ }^{5}$ We conventionally define as superfund the fund whose returns are calculated as average (equally weighted) monthly returns of all funds contained in the same segment for each investment style.

A first descriptive analysis on our sample (Table 1, Panel C) documents that SRFs outperform CFs in 8 out of 15 market segments: Europe, Asia/Pacific, Large, Europe Large, Asia Large, Global Middle/Small, Europe Middle/Small, and Asia Middle/Small categories in terms of difference in the average monthly returns $\left(\bar{R}_{t}^{d i f f}={\overline{R_{t}}}^{S R F}-{\overline{R_{t}}}^{C F}\right)$. The strongest difference in favor of the CFs is in the North America Middle/Small Area (.141 per cent), while that in favor of SR superfund is in the Global Middle/Small (.273 per cent). The standard deviation of monthly returns is higher for the SRFs in all segments, with the exception of the Middle/Small Cap and North America Middle/Small Cap categories.

Another interesting and counterintuitive finding is that the Global SRFs underperform SRFs operating in a specific Investment Area/Sector (Table 1, Panel A). The average monthly return

\footnotetext{
${ }^{4}$ Our final dataset is obtained after eliminating funds that: i) do not declare the Investment Area/Sector; ii) have less that 7 observations (due to estimation problems). Evidence that our main findings persist also without using these filtering criteria is available upon request.

${ }^{5}$ Data includes for SRFs 417 Global, 336 North America, 405 Europe, 55 Asia/Pacific, 1019 Large Cap, and 194 Middle/Small funds; and for CFs 4,541 Global, 11,004 North America, 5,673 Europe, 642 Asia/Pacific, 17,067 Large Cap, and 4,793 Middle/Small funds.
} 
of the Global SRFs is .43 against .66, .70, and .92 for, North America, Europe and Asia/Pacific SRFs respectively. The same occurs in the intersection between geographical segments and large cap funds, while results are more mixed when we consider the intersection with small/medium caps. Hence, from this first descriptive inspection, SRFs operating in a specific investment area/size do not seem to suffer much from the missed diversification opportunity problem unless we delimit the universe of investable funds to small/medium caps.

\section{Insert Table 1 About Here.}

In terms of Sharpe ratio $(S R)$, we estimate recursively (for the 3- and 5-Year window) for the relevant market segment the following specification:

$$
S R_{(t-w, t)}=\frac{\sum_{t=1}^{W}\left(\overline{R_{t}}-R_{f t}\right)}{W * \sigma_{w}}
$$

where $\overline{R_{t}}$ is the superfund's monthly return calculated at month $t ; R_{f t}$ is the risk-free rate in $t ; \sigma_{w}$ is the return' standard deviation calculated in the estimation window $(t-w, t)$ with $w$ being 3 - and 5-year and $t$ going from 1 to $W$ (where $W$ is the number of months in the given time window).

Panel A and B in Figure 2 report the recursive Sharpe Ratios as in (1) for the All Sample specification. ${ }^{6}$ It is worth noticing that when we compare recursive Sharpe ratios of the SR superfund versus the Conventional superfund calculated in 3-Year - Bauer et al. (2006) - and 5 -Year moving windows, we find that in all market segments there are several switches in dominance between the two investment styles. During the crisis of the 2007 SRFs outperform CFs in all market segments.

\section{Insert Figure 2 About Here.}

Based on what discussed above the three main facts which seem to emerge from our descriptive findings are: i) the absence of a clear cut dominance of one investment style over the other in the sample period of 1992-2012; ii) the superior performance of the SR superfunds during the 2007 global financial crisis; iii) the lack of superior performance of the Global SR superfund versus the SR superfund operating in specific investment area/size classes unless we delimit the universe of investable funds to small/medium caps.

\footnotetext{
${ }^{6}$ Sharpe ratios for specific investment segments are omitted for reasons of space and they are available from the authors upon request
} 


\section{Methodology and Econometric Results}

Our research section involves several approaches. First, following a standard methodology in the literature, we estimate a one factor model and a multi-factor model which includes, the market benchmark, the two Fama and French (1993) factors, Carhart (1996) - Momentum, and Bollen and Busse (2001) - Timing - risk factors. ${ }^{7}$ We do so in the overall sample period and in the subperiod of the global financial crisis. We repeat our estimates by considering the aggregate superfund and fund-by-fund approaches and by using the unbalanced sample and a sample matched with our original beta-distance nearest-neighbor approach. We finally reestimate the considered specifications with a recursive analysis on 3-Year and 5-Year estimation windows. More specifically, the standard baseline specification for the fully augmented five factor model is

$\left(R_{i t}-R_{f t}\right)=\alpha_{i}+\beta_{1 i} *\left(R_{m t}-R_{f t}\right)+\beta_{2 i} * S M B_{t}+\beta_{3 i} * H M L_{t}+\beta_{4 i} * M o M_{t}+\beta_{5 i} *\left(R_{m t}-R_{f t}\right)^{2}+\epsilon_{i t}$

where $\alpha$ is the Jensen's alpha; $\left(R_{i t}-R_{f t}\right)$ is the excess return of the fund $i$ in month $t$; $\left(R_{m t}-R_{f t}\right)$ is the monthly return of the stock market index used as a benchmark for each Investment Area/Sector specification; $S M B_{t}$ (Small Minus Big) is the Fama-French factor capturing exposition to small size risk calculated as the difference in returns between a small cap and a large cap portfolio; $H M L_{t}$ (High Minus Low) is the Fama-French factor capturing exposition to bankruptcy risk (which is presumably higher for companies having a low market value/book value ratio) calculated as the difference in returns between a portfolio of companies with high book-to-market and a portfolio of companies with low book-to-market; $M o M_{t}$ is the momentum risk factor based on the difference in returns of a portfolio with stocks with the highest returns in the last market period (eleven months) against those of a portfolio of stocks with the lowest returns in the same market period; $\left(R_{m t}-R_{f t}\right)^{2}$ is the square of the return of the benchmark index capturing the market timing risk factor. ${ }^{8}$

Empirical findings from the estimation of the five factor model in the unbalanced sample document that SR superfunds have positive and significant Jensen alphas in five segments (Table 2, Panel A) as well as Conventional superfunds (Table 2, Panel B). Results from the Difference superfunds (Table 2, Panel C) document a significantly superior performance of Conventional

\footnotetext{
${ }^{7}$ The Fama-French factors have been retrieved from the Kenneth French library at http : //mba.tuck.dartmouth.edu/pages/faculty/ken.french/datalibrary.html.

${ }^{8}$ As is well known market timing refers to the dynamic allocation of capital among broad classes of investment, often restricted to equities and short-term government debt. A successful market timing strategy consists of increasing the portfolio weight on equities prior to a stock market boom, while decreasing it prior to a stock market fall.
} 
superfunds only in the Global Large Investment segment, while no significant differences in all the other 14 segments. ${ }^{9}$

\section{Insert Table 2 About Here.}

As done for the Sharpe Ratio in descriptive statistics, we re-estimate the fully augmented five factor model recursively in 3-year - Bauer et al. (2006), and 5-year moving windows (Figures 3, Panel A and Panel B). ${ }^{10}$ We do not find a clear cut dominance of one investment style over the other during the overall sample period as documented by the several switches in relative dominance of Jensen's alpha. Note as well that the SR superfunds tend to outperform the Conventional superfunds in terms of Jensen's alpha during the 2007 financial crisis while not in the dot-com (high tech bubble) 2001 crisis, presumably due to their relatively higher exposition in high-tech stocks.

\section{Insert Figure 3 About Here.}

\section{Investment Style Matching}

The comparison of investment funds belonging to the same market segment (Global, Large Cap, etc.) is a reasonably accepted approximation when comparing fund managers with similar investment styles. However, our CF superfunds built for different segments may include in the computation of the average monthly returns many fund managers which have completely different risk profiles from those of the corresponding SRF managers - Geczy et al. (2005), Schroder (2004), and Gregory et al. (1997). This is all the more so given the much higher number of CFs funds which increases the probability of creating a spurious averaging process. A finer approach from this point of view consists in defining a matching procedure which balances the data in terms of exposure to risk factors. Our matching procedure works as follows. We estimate model (2) at fund by fund level, and then define the beta-distance $\left(d_{\beta}\right)$ between fund $i$ and fund $j$ as

$$
d_{\beta}(i, j)=\sum_{k=1}^{K}\left|\beta_{i k}-\beta_{j k}\right|
$$

where $\beta_{i k}$ is the value of the $k^{\text {th }}$ beta risk factor for the $i^{\text {th }} \mathrm{SRF}$, while $\beta_{j k}$ is the value of the $k^{\text {th }}$ beta risk factor for the $j^{\text {th }} \mathrm{CF}$.

\footnotetext{
${ }^{9}$ Results for the (one factor) market model are similar to those of the fully augmented five factor model. They are not reported for reasons of space and available from the authors upon request.

${ }^{10}$ Figure 3 reports the recursive Sharpe Ratios for the All Sample specification.
} 
We therefore select for each SRF $i$ the "nearest neighbour" CF $j$ that minimizes the $d_{\beta}(i, j)$. In this way we create a matched sample where each $\mathrm{CF}$ is joined with a corresponding SRF which is homogeneous in terms of exposure to risk factors. In order to avoid double counting we also follow the rule by which, when a given CF has been matched with a SRF, it cannot be matched again with any other fund and therefore it is excluded from the research of the following pairs.

Figure 4 shows the distribution (in deciles) of the alpha and other risk factors before and after the matching procedure. As is shown our procedure smooths the differences in the exposition to different risk factors between the two investment style - Nofsinger and Varma (2012).

\section{Insert Figure 4 About Here.}

Table 3 reports the descriptive statistics of the superfunds for the matched sample. ${ }^{11}$ Differently from the unbalanced sample, here SR superfunds perform better than Conventional superfunds in terms of aggregate returns in only 4 out of 15 market segments, while in all the remaining segments Conventional superfunds do better (Table 3 Panel C).

\section{Insert Table 3 About Here.}

As for the unbalanced sample, we compare also for the matched sample recursive Sharpe ratios - estimated as in (1) - of the SR supefunds versus the Conventional superfunds calculated in 3-Year - Bauer et al. (2006) - and 5-Year moving windows for the matched sample and find that in all market segments there are several switches in dominance between the two investment styles (Figure 5 Panel A and Panel B). During the crisis of the 2007 SRFs outperform CFs in all market segments (while underperforming them in the dot-com 2001 crisis).

\section{Insert Figure 5 About Here.}

We finally estimate the five factor model specification for the superfunds in the matched sample (Table 4). Differently from the unbalanced estimations in Table 2, here empirical findings from the balanced sample strongly document that SR superfunds have positive and significant Jensen alphas in eleven out of fifteen segments (Table 4, Panel A). The same happens for Conventional superfunds (Table 4, Panel B). Jensen's alphas for the Difference superfund (Table 4, Panel C) document the superior performance of Conventional superfunds in the Global and Global

\footnotetext{
${ }^{11}$ Note that, due to the matched technique here Panel A is the same asPanel A in Table 1, while Panel B is the result of the matching a CF with the "nearest neighbour" SRF.
} 
Large investment segments, while the SR superfund outperforms the Conventional superfund in the Global Middle/Small investment area/size. ${ }^{12}$ The investment area/size breakdown does not document any other dominance of one investment style over the other. As expected, our matching procedure reduces by far differences in exposure to risk factors between the two investment styles with respect to Table 2 .

\section{Insert Table 4 About Here.}

As in the case of the unbalanced sample, we estimate for the matched sample the five factor model recursively in 3-year - Bauer et al. (2006) - and 5-year moving windows. We do not find a clear cut dominance of one investment style over the other. As in the one factor model, we find several switches in relative dominance of Jensen's alphas (Figures 6, Panel A and Panel B). Note as well that SR superfunds tend to outperform Conventional in terms of Jensen's alphas during the crisis of the 2007 .

\section{Insert Figure 6 About Here.}

We finally perform our analysis also at fund by fund level using the matched sample created with the procedure in (3). From model (2) estimated at fund level, we extract the (investment style specific) distribution for each risk factor and for the Jensen's alphas. We then test the null hypothesis that the two (CF and SRF) alpha distributions do not differ in mean with the following t-test specification:

$$
t_{m . n}=\frac{\overline{\alpha_{S R F}}-\overline{\alpha_{C F}}}{\sqrt{\sigma_{S R F}^{2}(n-1)+\sigma_{C F}^{2}(m-1)}} \sqrt{\frac{n m(n+m-2)}{n+m}} \sim \tau_{n+m-2}
$$

where $\overline{\alpha_{S R F}}$ is the average alpha of the SRFs distribution, $\overline{\alpha_{C F}}$ is the average alpha of the CFs distribution, $\sigma_{S R F}^{2}$ is the variance of the SRFs' alpha distribution, $\sigma_{C F}^{2}$ is the variance of the CFs' alpha distribution, $n$ is the SRF sample size, $m$ is the CF sample size, and $n+m-2$ are the degrees of freedom.

Table 5 (Panel A and Panel B) shows that for both investment styles most of the alphas are negative and significant during the overall sample period with the exception of Asia/Pacific Middle/Small for SRFs and Europe Middle/Small for CFs. Table 5 (Panel C) shows that the null is rejected in direction of a superior performance of CFs for the All Sample, Global, Europe and Global Large segments, while in favor of the SRFs for the Asia/Pacific and Asia/Pacific Large segments. In all the remaining nine segments the null is not rejected.

\footnotetext{
${ }^{12}$ Again, results for the (one factor) market model are similar to those of the fully augmented five factor model. They are not reported and available from the authors upon request.
} 


\section{Insert Table 5 About Here.}

Table 6 reports results from testing the same null hypothesis in the sub-period of the 2007 crisis. Table 6 (Panel A and Panel B) shows mixed results for both investment styles, while Table 6 (Panel C) points out that SRFs outperform CFs in seven segments (Global, Europe, Asia, Europe Large, Asia Large, and Europe Medium/Small), while the difference in the remaining seven segments is not significant. Hence the superiority of the SRFs in the 2007 crisis is quite clear cut in this case.

\section{Insert Table 6 About Here.}

Figure 7 (Panel A and Panel B) reports Jensen alphas of the fully augmented five factor model estimated recursively in 3-year (Bauer et al. (2006)) and 5-year moving windows at fund by fund level. We do not find a clear cut dominance of one investment style over the other. As in the aggregate approach, we find several switches in relative dominance. Note as well that SRFs tend to outperform CFs during the financial crisis of the 2007 (while not, again, in the 2001 dot-com crisis).

\section{Insert Figure 7 About Here.}

\section{Conclusions}

We provide a novel and original contribution to the literature by comparing (in a large number of Morningstar funds dataset) the performance of SRFs versus CFs extending the period of analysis to the global financial crisis and adopting an original (nearest neighbor) matching approach in terms of exposure to risk factors.

We find three main results which are confirmed by descriptive evidence, by econometric evidence with standard one-factor/multi-factor models, and by our nearest neighbor approach which looks at differences in Jensen's alphas between pairs of SRFs and CFs which are as close as possible in terms of exposition to risk factors.

First, there is no clear cut dominance over the entire period and in all segments of one investment style over the other. The lack of clear cut dominance is confirmed by the several switches in the lead/lag relationship between Jensen's alphas of our SR superfunds and Conventional superfunds in all market segments. Second, all the considered approaches seem to indicate that SR superfunds generally do better than Conventional superfunds in the period following the global financial crisis (while not in the dot-com 2001 crisis presumably due to their higher 
exposition to high-tech stocks). Third, the limited diversification constraint does not seem to be a problem for SRFs, unless we delimit the universe of investable funds to small/medium caps, since the SR superfunds in limited (Investment or Size area) market segments do not perform worse than the Global SR superfund in all the other cases.

The first of our main results shows that the limited diversification cost does not compromise the performance of SRFs. This is also confirmed by the third result where within the SRFs investment style, the SRFs with market segment constraints are not penalized with respect to the Global SFRs if we do not constrain the universe of investable funds to Small/Medium caps. The second result that we obtain (the superior performance of SRFs in the global financial crisis) makes us wonder whether SR superfund may be conceived as an insurance which protects against an ethical risk factor whose risk accumulates in market booms (where ethical investors pay a premium in terms of lower returns) and produces its negative consequences in financial crises where ethical investors cash their insurance indemnity (that is, earn a portfolio return which is superior to that of non ethical investors). This interpretation is however less acceptable if we consider that SRFs did not perform equally well in the 2001 dot-com crisis due to their relatively higher exposition on high-tech stocks.

Overall our findings document that the three additional costs for SRFs in terms of fund management do not hit or are compensated by the potential benefits of CSR on corporate performance (minimisation of conflicts with stakeholders, leadership in environmental innovation, higher demand from socially and environmentally concerned consumers, positive effects on workers productivity, etc.) identified by the literature. 


\section{References}

G. A. Akerlof. Labor contracts as partial gift exchange. The Quarterly Journal of Economics, 97(4):543-69, November 1982.

M. L. Barnett and R. M. Salomon. Beyond dichotomy: The curvilinear relationship between social responsibility and financial performance. Strategic Management Journal, 27(11):1101$1122,2006$.

R. Bauer, K. Koedijk, and R. Otten. International evidence on ethical mutual fund performance and investment style. Journal of Banking and Finance, 29(7):1751-1767, 2005.

R. Bauer, R. Otten, and A. Tourani Rad. Ethical investing in australia: Is there a financial penalty? Pacific-Basin Finance Journal, 14(1):111-124, 2006.

L. Becchetti, R. Ciciretti, I. Hasan, and N. Kobeissi. Corporate social responsibility and shareholder value: A note. Journal of Business Research, 65:1628-1635, 2012.

L. Becchetti, R. Ciciretti, and A. Giovannelli. Corporate social responsibility and earnings forecasting unbiasedness. Journal of Banking and Finance, 37(9):3654-3668, 2013.

N. P. B. Bollen and J. A. Busse. On the timing ability of mutual fund managers. Journal of Finance, 56(3):1075-1094, 2001.

M. M. Carhart. On persistence in mutual fund performance. Journal of Finance, 52(1):57-82, 1996.

European Commission. Promoting a European framework for corporate social responsibility. Technical report, Directorate General for Employment and Social Affairs, 2001.

A. Crane, A. McWilliams, D. Matten, J. Moon, and D. S. Siegel, editors. The Oxford Handbook of Corporate Social Responsibility. Oxford University Press, August 2009.

J. Derwall, N. Guenster, R. Bauer, and K. Koedijk. The eco-efficiency premium puzzle. inancial Analysts Journal, 61:51-63, 2011.

A. Edmans. Does the stock market fully value intangibles? employee satisfaction and equity prices. Journal of Financial Economics, 101:621-640, 2011.

E. Fama and K. R. French. Common risk factors in the returns on stocks and bonds. Journal of Financial Economics, 33(1):3-53, 1993.

E. Fama and K. R. French. Multifactor explanations of asset pricing anomalies. Journal of Finance, 51(1):55-84, 1996. 
Social Investment Forum Foundation. Report on Socially Responsible Investing Trends in the United States. Technical report, Social Investment Forum Foundation, 2010.

C. C. Geczy, R. F. Stambaugh, and D. Levin. Investing in socially responsible mutual funds. Working Paper Rodney L. White Center for Financial Research, Wharton School, University of Pennsylvania, 2005.

A. Gregory, J. Matatko, and R. Luther. Ethical unit trust financial performance: small company effects and fund size effects. Journal of Business Finance and Accounting, 24(5):705-725, 1997.

S. Herzel, M. Nicolosi, and C. Starica. The cost of sustainability in optimal portfolio decisions. European Journal of Finance, 18(3-4):333-349, 2012.

M. C. Jensen. The performance of mutual funds in the period 1945-1964. Journal of Finance, 23(2):389-416, 1968.

A. Kempf and P. Osthoff. The effect of socially responsible investing on portfolio performance. European Financial Management, 13(5):908-922, 2007.

J. R. Nofsinger and A. Varma. Socially responsible funds and market crises. Working Paper SSRN, 2012.

L. Renneboog, J. Ter Horst, and C. Zhang. The price of ethics: Evidence from socially responsible mutual funds around the world. Working Paper Tilburg University, 2007.

L. Renneboog, J. Ter Horst, and C. Zhang. Socially responsible investments: Institutional aspects, performance, and investor behaviour. Journal of Banking and Finance, 32(9):17231742, 2008a.

L. Renneboog, J. Ter Horst, and C. Zhang. The price of ethics and stakeholder governance: The performance of socially responsible mutual funds. Journal of of Corporate Finance, 14 (3):302-322, 2008b.

M. Schroder. The performance of socially responsible investments: investment funds and indices. Financial Markets and Portfolio Management, 18(2):122-142, 2004. 


\section{Figures}
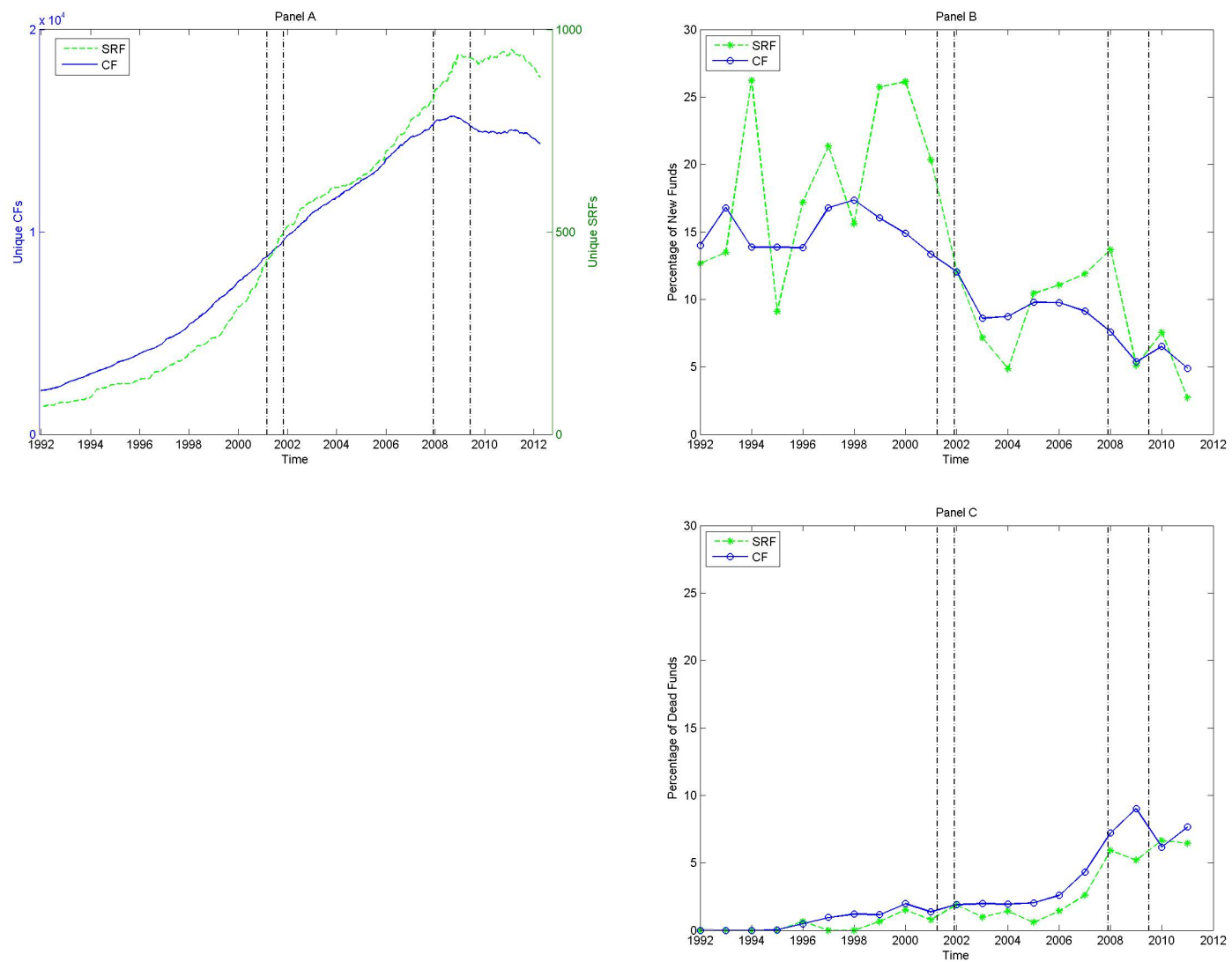

Figure 1: Panel A: number of unique funds (upper left) in Morningstar data for each month $t$; Panel B: percentage of new funds over the unique funds (upper right) at yearly level; Panel C: percentage of dead funds over the unique funds (bottom right) at yearly level. 

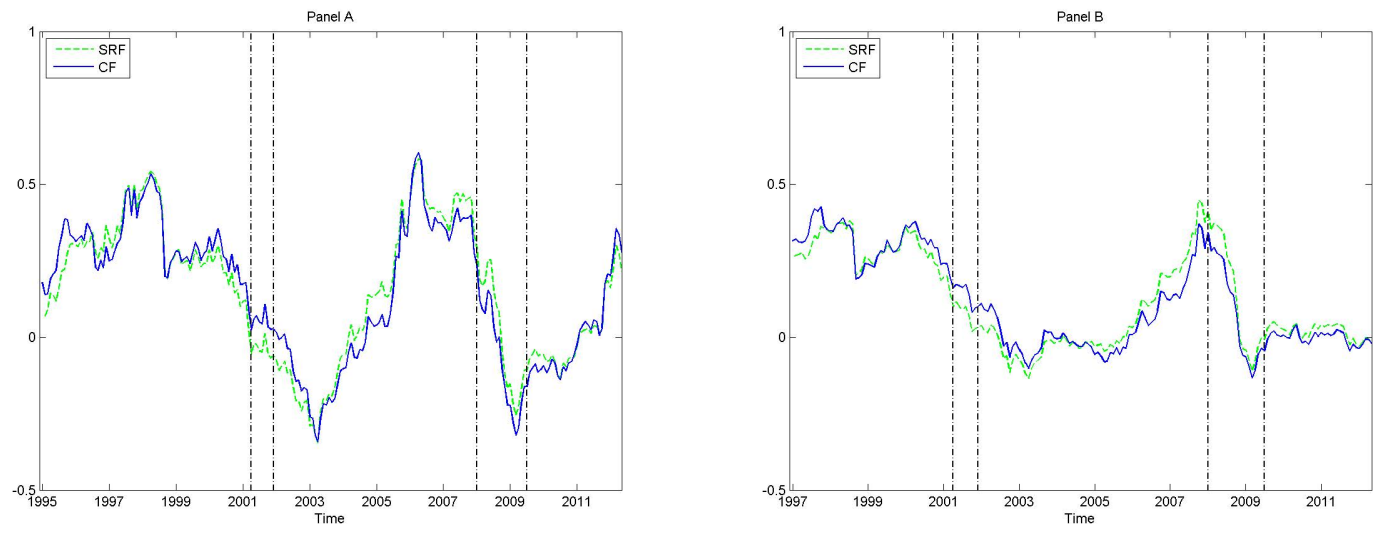

Figure 2: Panel A: Recursive Sharpe Ratio 3-Year estimation window (left) for the unbalanced sample of the SR and Conventional superfunds (All Sample specification); Panel B: Recursive Sharpe Ratio 5-Year estimation window (right) for the unbalanced sample of the SR and Conventional superfunds (All Sample specification).
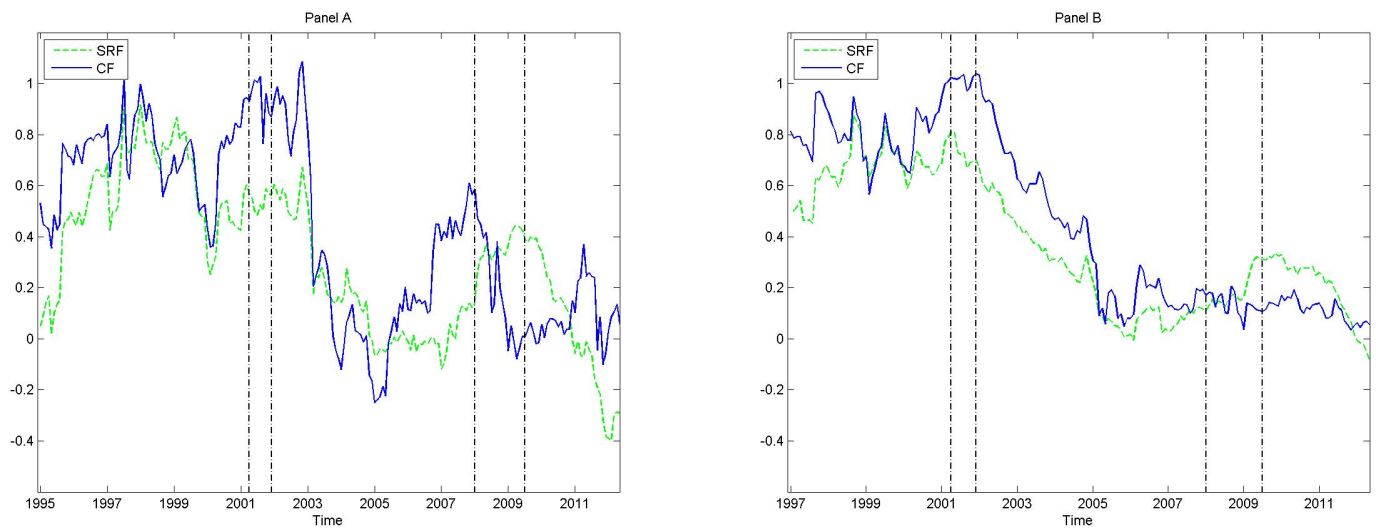

Figure 3: Panel A: Recursive Alpha 3-Year estimation window (left) for the unbalanced sample SR and Conventional superfunds (All Sample specification); Panel B: Recursive Alpha 5Year estimation window (left) for the unbalanced sample SR and Conventional superfunds (All Sample specification). 

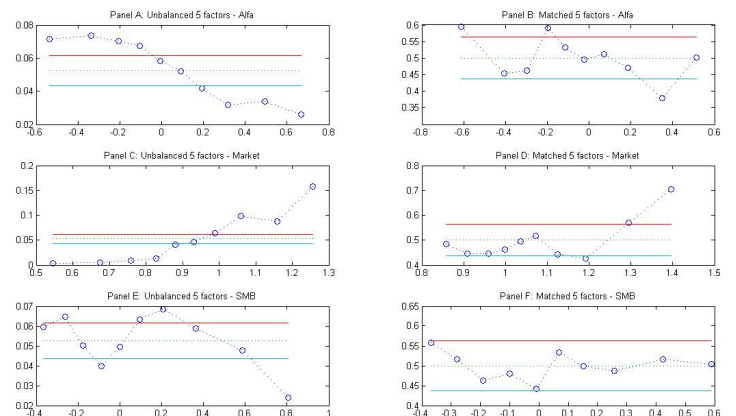
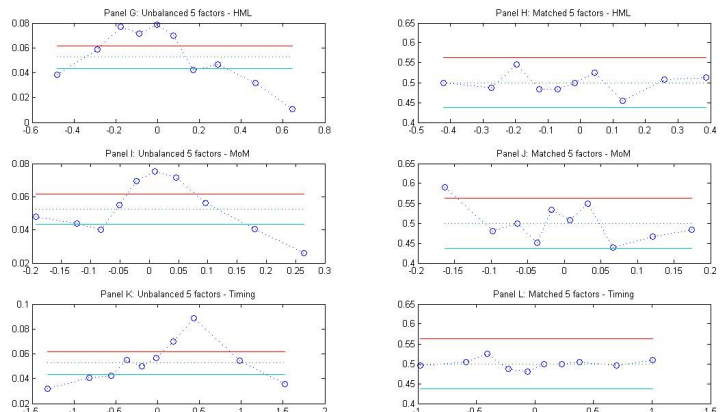

Figure 4: Distributions (in deciles) of alpha and other risk factors for the unbalanced sample and for the matched sample (All Sample specification). Panel A and Panel B: alpha for unbalanced and matched sample respectively; Panel $\mathbf{C}$ and Panel D: $S M B$ for unbalanced and matched sample respectively; Panel E and Panel F: Market for unbalanced and matched sample respectively; Panel G and Panel H: $H M L$ for unbalanced and matched sample respectively; Panel I and Panel J: $M o M$ for unbalanced and matched sample respectively; Panel $\mathbf{K}$ and Panel L: Timing for unbalanced and matched sample respectively;
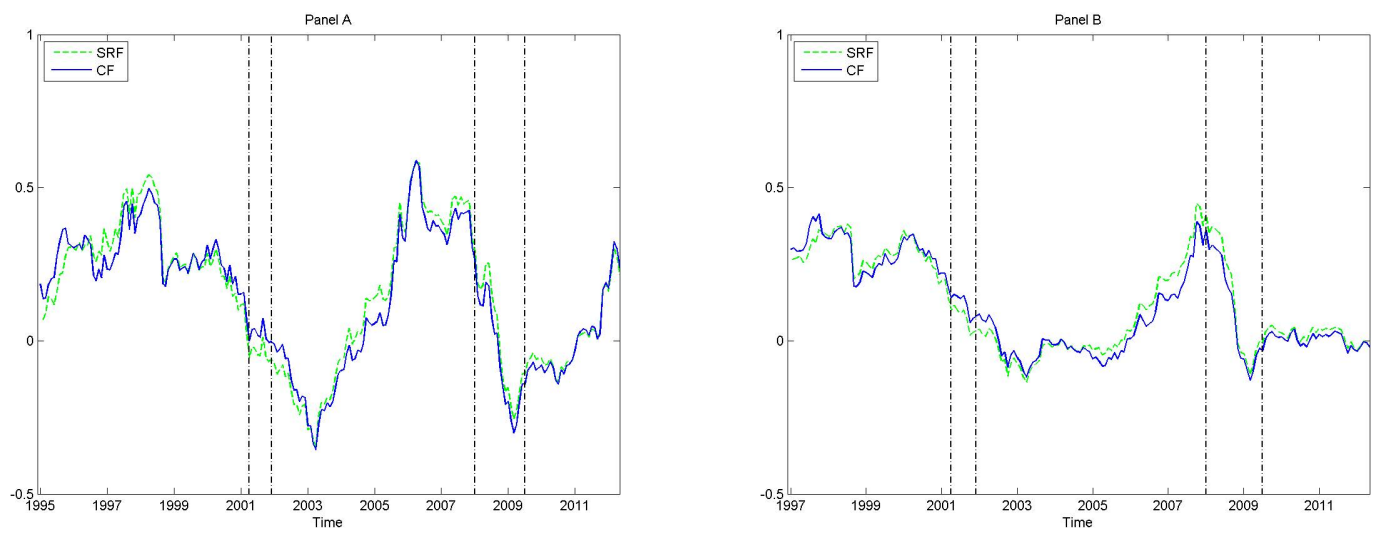

Figure 5: Panel A: Recursive Sharpe Ratio 3-Year estimation window (left) for the matched sample SR and Conventional superfunds (All Sample specification); Panel B: Recursive Sharpe Ratio 5-Year estimation window (right) for the matched sample SR and Conventional superfunds (All Sample specification). 

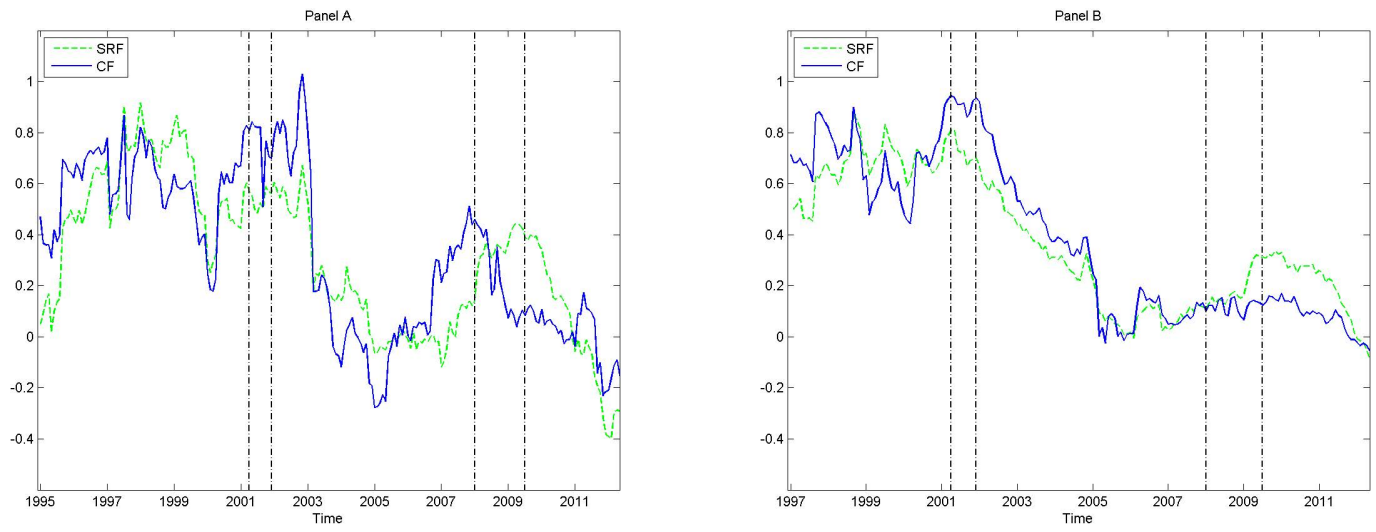

Figure 6: Panel A: Recursive alpha 3-Year estimation window (left) for the matched sample SR and Conventional superfunds (All Sample specification); Panel B: Recursive alpha 5-Year estimation window (left) for the matched sample SR and Conventional superfunds (All Sample specification).
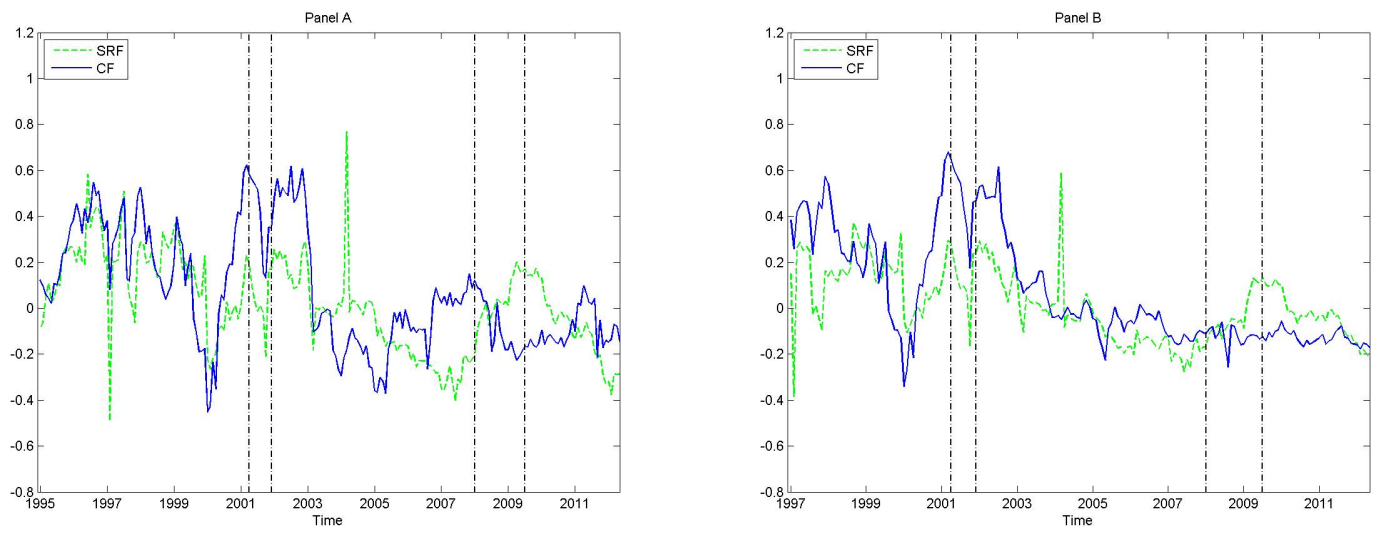

Figure 7: Panel A: Recursive alpha 3-Year estimation window (left) for the matched sample fund by fund SRF and CF (All Sample specification); Panel B: Recursive alpha 5-Year estimation window (left) for the matched sample fund by fund SRF and CF (All Sample specification). 
Table 1: Descriptive Statistics for SR, Conventional, and Difference (SRF-CF) superfunds Unbalanced Sample

\begin{tabular}{|c|c|c|c|c|c|c|c|c|c|c|}
\hline \multicolumn{11}{|c|}{ Panel A: SRFs } \\
\hline & & $\begin{array}{c}\text { ShR } \\
(1)\end{array}$ & $\begin{array}{c}\overline{R_{t}} S R F \\
(2)\end{array}$ & $\underset{(3)}{\min }$ & $\max _{(4)}$ & $\begin{array}{c}\text { p50 } \\
(5)\end{array}$ & st. dev. & $\begin{array}{c}\text { skew. } \\
(7)\end{array}$ & $\underset{(8)}{\text { kurt. }}$ & $\begin{array}{l}\mathbf{N} \\
(9)\end{array}$ \\
\hline & All Sample & 0.084 & 0.643 & -21.980 & 12.929 & 1.129 & 4.615 & -0.854 & 5.576 & 244 \\
\hline \multirow[t]{4}{*}{ Inv Area } & Global & 0.039 & 0.426 & -21.382 & 11.454 & 0.713 & 4.372 & -0.873 & 5.597 & 244 \\
\hline & North America & 0.089 & 0.656 & -18.768 & 12.466 & 1.115 & 4.487 & -0.729 & 4.709 & 244 \\
\hline & Europe & 0.084 & 0.697 & -24.260 & 15.050 & 1.135 & 5.257 & -0.683 & 5.176 & 244 \\
\hline & Asia & 0.118 & 0.918 & -26.978 & 16.831 & 1.169 & 5.588 & -0.594 & 5.837 & 244 \\
\hline \multirow[t]{2}{*}{ Inv Size } & Large (L) & 0.079 & 0.624 & -21.852 & 12.496 & 1.151 & 4.617 & -0.842 & 5.519 & 244 \\
\hline & Middle/Small (M/S) & 0.101 & 0.741 & -22.598 & 15.120 & 1.001 & 4.771 & -0.824 & 5.546 & 244 \\
\hline \multirow[t]{8}{*}{ Inv Area/Size } & Global-L & 0.036 & 0.414 & -21.181 & 11.355 & 0.763 & 4.372 & -0.856 & 5.497 & 244 \\
\hline & North America-L & 0.086 & 0.626 & -17.786 & 11.610 & 1.094 & 4.318 & -0.688 & 4.549 & 244 \\
\hline & Europe-L & 0.084 & 0.704 & -24.034 & 14.717 & 1.185 & 5.359 & -0.663 & 4.973 & 244 \\
\hline & Asia-L & 0.103 & 0.829 & -26.737 & 16.953 & 0.877 & 5.552 & -0.541 & 5.758 & 244 \\
\hline & Global-M/S & 0.162 & 1.117 & -25.731 & 13.657 & 1.870 & 5.331 & -0.910 & 5.577 & 215 \\
\hline & North America-M/S & 0.096 & 0.733 & -20.297 & 14.218 & 1.159 & 4.982 & -0.686 & 4.627 & 244 \\
\hline & Europe-M/S & 0.089 & 0.686 & -22.164 & 13.724 & 1.117 & 4.820 & -0.770 & 5.361 & 244 \\
\hline & Asia-M/S & 0.138 & 1.143 & -28.861 & 16.762 & 1.674 & 6.466 & -0.644 & 5.362 & 210 \\
\hline \multicolumn{11}{|c|}{ Panel B: CFs } \\
\hline & & $\begin{array}{c}\text { ShR } \\
(1)\end{array}$ & $\begin{array}{c}\bar{R}_{t} C F \\
(2)\end{array}$ & $\underset{(3)}{\min }$ & $\max _{(4)}$ & $\begin{array}{c}\text { p50 } \\
(5)\end{array}$ & st. dev. & $\begin{array}{c}\text { skew. } \\
(7)\end{array}$ & $\underset{(8)}{\text { kurt. }}$ & $\begin{array}{l}\mathbf{N} \\
(9)\end{array}$ \\
\hline \multirow{5}{*}{ Inv Area } & All Sample & 0.101 & 0.680 & -16.448 & 11.488 & 1.392 & 4.202 & -0.830 & 4.509 & 244 \\
\hline & Global & 0.072 & 0.548 & -14.030 & 10.573 & 1.045 & 4.060 & -0.692 & 3.851 & 244 \\
\hline & North America & 0.107 & 0.733 & -18.188 & 11.696 & 1.368 & 4.445 & -0.786 & 4.560 & 244 \\
\hline & Europe & 0.088 & 0.658 & -15.541 & 13.404 & 1.249 & 4.537 & -0.669 & 4.171 & 244 \\
\hline & Asia & 0.157 & 0.829 & -12.736 & 7.870 & 1.322 & 3.645 & -0.756 & 3.846 & 244 \\
\hline \multirow[t]{2}{*}{ Inv Size } & Large (L) & 0.090 & 0.620 & -15.269 & 10.652 & 1.264 & 4.048 & -0.824 & 4.315 & 244 \\
\hline & Middle/Small (M/S) & 0.125 & 0.875 & -20.483 & 14.385 & 1.524 & 4.937 & -0.719 & 4.829 & 244 \\
\hline \multirow[t]{8}{*}{ Inv Area/Size } & Global-L & 0.066 & 0.523 & -13.702 & 10.007 & 1.004 & 4.040 & -0.695 & 3.755 & 244 \\
\hline & North America-L & 0.097 & 0.662 & -16.771 & 10.757 & 1.210 & 4.194 & -0.777 & 4.391 & 244 \\
\hline & Europe-L & 0.081 & 0.622 & -14.961 & 13.007 & 1.275 & 4.514 & -0.654 & 3.990 & 244 \\
\hline & Asia-L & 0.145 & 0.779 & -11.328 & 7.820 & 1.323 & 3.615 & -0.672 & 3.521 & 244 \\
\hline & Global-M/S & 0.113 & 0.844 & -20.552 & 19.264 & 1.225 & 5.222 & -0.349 & 5.289 & 215 \\
\hline & North America-M/S & 0.121 & 0.875 & -20.826 & 14.409 & 1.356 & 5.129 & -0.667 & 4.568 & 244 \\
\hline & Europe-M/S & 0.099 & 0.680 & -16.267 & 11.010 & 1.309 & 4.292 & -0.783 & 4.338 & 244 \\
\hline & Asia-M/S & 0.195 & 1.123 & -20.900 & 8.636 & 2.089 & 4.446 & -1.207 & 5.714 & 210 \\
\hline \multicolumn{11}{|c|}{ Panel C: SRFs-CFs } \\
\hline & & $\begin{array}{c}\text { ShR } \\
(1)\end{array}$ & $\begin{array}{c}\overline{R_{t}} \text { diff } \\
\text { (2) }\end{array}$ & $\underset{(3)}{\min }$ & $\max _{(4)}$ & $\begin{array}{c}\mathbf{p 5 0} \\
(5)\end{array}$ & $\begin{array}{l}\text { st. dev. } \\
(6)\end{array}$ & $\begin{array}{c}\text { skew. } \\
(7)\end{array}$ & $\underset{(8)}{\text { kurt. }}$ & $\begin{array}{l}\mathbf{N} \\
(9)\end{array}$ \\
\hline \multirow{5}{*}{ Inv Area } & All Sample & - & -0.037 & -5.532 & 4.690 & 0.010 & 1.492 & -0.445 & 4.370 & 244 \\
\hline & Global & - & -0.121 & -7.352 & 5.603 & -0.005 & 2.244 & -0.287 & 3.226 & 244 \\
\hline & North America & - & -0.077 & -3.404 & 2.960 & -0.101 & 0.625 & -0.094 & 7.998 & 244 \\
\hline & Europe & - & 0.039 & -9.249 & 7.017 & 0.146 & 2.771 & -0.311 & 3.495 & 244 \\
\hline & Asia & - & 0.089 & -14.242 & 12.105 & 0.228 & 3.540 & -0.155 & 4.221 & 244 \\
\hline \multirow[t]{2}{*}{ Inv Size } & Large (L) & - & 0.003 & -6.583 & 5.271 & -0.040 & 1.650 & -0.363 & 4.469 & 244 \\
\hline & Middle/Small (M/S) & - & -0.135 & -7.320 & 8.194 & -0.141 & 1.457 & -0.316 & 10.327 & 244 \\
\hline \multirow[t]{8}{*}{ Inv Area/Size } & Global-L & - & -0.110 & -7.479 & 5.799 & -0.064 & 2.318 & -0.254 & 3.189 & 244 \\
\hline & North America-L & - & -0.035 & -2.512 & 2.352 & -0.028 & 0.605 & -0.023 & 5.417 & 244 \\
\hline & Europe-L & - & 0.083 & -9.568 & 7.183 & 0.133 & 2.833 & -0.340 & 3.585 & 244 \\
\hline & Asia-L & - & 0.050 & -15.409 & 12.951 & 0.086 & 3.638 & -0.155 & 4.469 & 244 \\
\hline & Global-M/S & - & 0.273 & -24.632 & 13.230 & 0.619 & 3.915 & -1.283 & 11.222 & 215 \\
\hline & North America-M/S & - & -0.141 & -3.942 & 4.581 & -0.131 & 0.952 & 0.339 & 6.345 & 244 \\
\hline & Europe-M/S & - & 0.005 & -5.897 & 6.863 & -0.034 & 1.860 & 0.091 & 3.785 & 244 \\
\hline & Asia-M/S & - & 0.021 & -9.045 & 8.855 & 0.039 & 3.680 & 0.097 & 2.899 & 210 \\
\hline
\end{tabular}

Legend: The Table reports average monthly returns $\left(\overline{R_{t}}\right)$, Sharpe Ratios $(\mathbf{S h R})$ and other descriptive statistics for the SR Superfunds (Panel A), the conventional Superfunds (Panel B) and the Difference Superfunds (SRF-CF) (Panel C) in the unbalanced sample. 
Table 2: Five factor model estimations for SR, Conventional, and Difference (SRF-CF) Superfunds - Unbalanced Sample

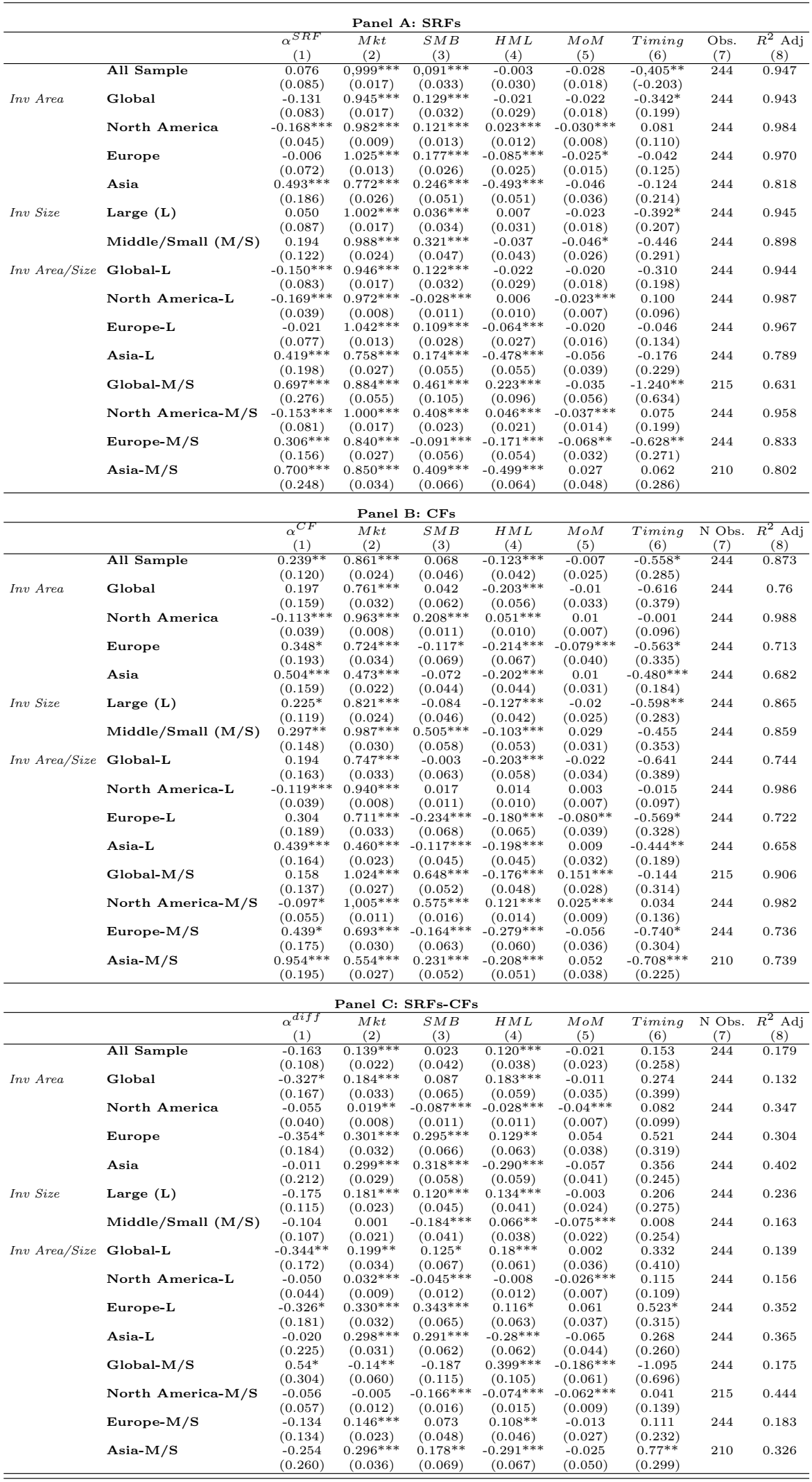

Legend: The Table reports estimate findings of the five factor model for SR Superfunds (Panel A), Conventional Superfunds (Panel B), and Difference Superfunds (SRF-CF) (Panel C) in the unbalanced sample.

$\alpha$ is the Jensen' alpha that captures fund manager contribution to financial performance; $M k t$ is the monthly return of the stock market index used as benchmark for each Investment Area/Sector specifications; $S M B$ (Small Minus Big) is the factor capturing exposition to small size risk calculated as the difference in returns between a small cap and a large cap portfolio at the same time t; $H M L$ (High Minus Low) is the factor capturing exposition to bankruptcy risk calculated as the difference in returns between a portfolio of companies with high book-tomarket and a portfolio of companies with low book-to-market at the same time t; $M o M$ is the momentum risk factor based on the difference in returns of a portfolio with stocks with the highest returns in the last market period (eleven months) against those of a portfolio of stocks with the lowest returns in the same market period; Timing is the timing risk factor calculated as the square of the return of the benchmark index.

${ }^{*} p$-value $<0.05,{ }^{* *} p$-value $<0.01,{ }^{* * *} p$-value $<0.001 ;$ (Robust Standard Errors). 
Table 3: Descriptive Statistics for SR, Conventional, and Difference (SRF-CF) superfunds Matched Sample

\begin{tabular}{|c|c|c|c|c|c|c|c|c|c|c|}
\hline \multicolumn{11}{|c|}{ Panel A: SRFs } \\
\hline & & $\begin{array}{c}\text { ShR } \\
(1)\end{array}$ & $\begin{array}{c}\overline{R_{t}} S R F \\
(2)\end{array}$ & $\min _{(3)}$ & $\max _{(4)}$ & $\begin{array}{c}\mathbf{p 5 0} \\
(5)\end{array}$ & st. dev. & $\begin{array}{c}\text { skew. } \\
(7)\end{array}$ & $\underset{(8)}{\text { kurt. }}$ & $\begin{array}{l}\mathbf{N} \\
(9)\end{array}$ \\
\hline & All Sample & 0.084 & 0.643 & -21.980 & 12.929 & 1.129 & 4.615 & -0.854 & 5.576 & 244 \\
\hline \multirow[t]{4}{*}{ Inv Area } & Global & 0.039 & 0.426 & -21.382 & 11.454 & 0.713 & 4.372 & -0.873 & 5.597 & 244 \\
\hline & North America & 0.089 & 0.656 & -18.768 & 12.466 & 1.115 & 4.487 & -0.729 & 4.709 & 244 \\
\hline & Europe & 0.084 & 0.697 & -24.260 & 15.050 & 1.135 & 5.257 & -0.683 & 5.176 & 244 \\
\hline & Asia & 0.118 & 0.918 & -26.978 & 16.831 & 1.169 & 5.588 & -0.594 & 5.837 & 244 \\
\hline \multirow[t]{2}{*}{ Inv Size } & Large (L) & 0.079 & 0.624 & -21.852 & 12.496 & 1.151 & 4.617 & -0.842 & 5.519 & 244 \\
\hline & Middle/Śmall (M/S) & 0.101 & 0.741 & -22.598 & 15.120 & 1.001 & 4.771 & -0.824 & 5.546 & 244 \\
\hline \multirow[t]{8}{*}{ Inv Area/Size } & Global-L & 0.036 & 0.414 & -21.181 & 11.355 & 0.763 & 4.372 & -0.856 & 5.497 & 244 \\
\hline & North America-L & 0.086 & 0.626 & -17.786 & 11.610 & 1.094 & 4.318 & -0.688 & 4.549 & 244 \\
\hline & Europe-L & 0.084 & 0.704 & -24.034 & 14.717 & 1.185 & 5.359 & -0.663 & 4.973 & 244 \\
\hline & Asia-L & 0.103 & 0.829 & -26.737 & 16.953 & 0.877 & 5.552 & -0.541 & 5.758 & 244 \\
\hline & Global-M/S & 0.162 & 1.117 & -25.731 & 13.657 & 1.870 & 5.331 & -0.910 & 5.577 & 215 \\
\hline & North America-M/S & 0.096 & 0.733 & -20.297 & 14.218 & 1.159 & 4.982 & -0.686 & 4.627 & 244 \\
\hline & Europe-M/S & 0.089 & 0.686 & -22.164 & 13.724 & 1.117 & 4.820 & -0.770 & 5.361 & 244 \\
\hline & Asia-M/S & 0.138 & 1.143 & -28.861 & 16.762 & 1.674 & 6.466 & -0.644 & 5.362 & 210 \\
\hline \multicolumn{11}{|c|}{ Panel B: CFs } \\
\hline & & $\begin{array}{c}\text { ShR } \\
(1)\end{array}$ & $\begin{array}{c}\bar{R}_{t} C F \\
(2)\end{array}$ & $\min _{(3)}$ & $\max _{(4)}$ & $\begin{array}{l}\mathbf{p 5 0} \\
(5)\end{array}$ & st. dev. & $\begin{array}{l}\text { skew. } \\
(7)\end{array}$ & $\begin{array}{c}\text { kurt. } \\
(8)\end{array}$ & $\begin{array}{l}\mathbf{N} \\
(9)\end{array}$ \\
\hline & All Sample & 0.090 & 0.672 & -19.240 & 12.793 & 1.513 & 4.637 & -0.800 & 4.740 & 244 \\
\hline \multirow[t]{4}{*}{ Inv Area } & Global & 0.077 & 0.598 & -18.830 & 11.094 & 0.948 & 4.456 & -0.758 & 4.524 & 244 \\
\hline & North America & 0.096 & 0.680 & -18.164 & 12.053 & 1.294 & 4.389 & -0.757 & 4.570 & 244 \\
\hline & Europe & 0.114 & 0.826 & -19.609 & 14.777 & 1.567 & 4.978 & -0.599 & 4.636 & 244 \\
\hline & Asia & 0.119 & 0.870 & -18.565 & 12.577 & 1.676 & 5.152 & -0.678 & 3.930 & 244 \\
\hline \multirow[t]{2}{*}{ Inv Size } & Large (L) & 0.082 & 0.637 & -19.013 & 12.450 & 1.332 & 4.616 & -0.788 & 4.681 & 244 \\
\hline & Middle/Small (M/S) & 0.117 & 0.828 & -20.521 & 14.327 & 1.323 & 4.882 & -0.750 & 4.884 & 244 \\
\hline \multirow[t]{8}{*}{ Inv Area/Size } & Global-L & 0.073 & 0.579 & -18.630 & 10.891 & 0.952 & 4.433 & -0.766 & 4.481 & 244 \\
\hline & North America-L & 0.089 & 0.633 & -17.119 & 11.314 & 1.183 & 4.223 & -0.741 & 4.437 & 244 \\
\hline & Europe-L & 0.108 & 0.796 & -19.491 & 13.985 & 1.402 & 4.982 & -0.597 & 4.445 & 244 \\
\hline & Asia-L & 0.111 & 0.804 & -17.191 & 13.090 & 1.535 & 4.952 & -0.687 & 3.918 & 244 \\
\hline & Global-M/S & 0.085 & 0.712 & -23.228 & 15.735 & 1.289 & 5.343 & -0.617 & 5.027 & 214 \\
\hline & North America-M/S & 0.118 & 0.833 & -20.550 & 13.974 & 1.443 & 4.891 & -0.699 & 4.687 & 244 \\
\hline & Europe-M/S & 0.098 & 0.701 & -18.393 & 13.195 & 1.158 & 4.551 & -0.706 & 4.700 & 244 \\
\hline & Asia-M/S & 0.169 & 1.172 & -25.263 & 13.394 & 1.706 & 6.038 & -0.983 & 5.282 & 130 \\
\hline \multicolumn{11}{|c|}{ Panel C: SRFs-CFs } \\
\hline & & $\begin{array}{c}\text { ShR } \\
(1)\end{array}$ & $\begin{array}{c}\overline{R_{t}} \text { diff } \\
(2)\end{array}$ & $\begin{array}{c}\min \\
(3)\end{array}$ & $\max _{(4)}$ & $\begin{array}{c}\text { p50 } \\
(5)\end{array}$ & $\begin{array}{l}\text { st. dev. } \\
(6)\end{array}$ & $\begin{array}{l}\text { skew. } \\
(7)\end{array}$ & $\begin{array}{c}\text { kurt. } \\
(8)\end{array}$ & $\begin{array}{l}\mathbf{N} \\
(9)\end{array}$ \\
\hline \multirow{5}{*}{ Inv Area } & All Sample & - & -0.029 & -4.661 & 2.808 & 0.016 & 1.138 & -0.537 & 4.061 & 244 \\
\hline & Global & - & -0.171 & -4.447 & 3.669 & 0.009 & 1.385 & -0.457 & 3.254 & 244 \\
\hline & North America & - & -0.024 & -1.543 & 1.761 & -0.034 & 0.484 & 0.042 & 4.444 & 244 \\
\hline & Europe & - & -0.130 & -10.000 & 5.432 & 0.002 & 2.097 & -0.899 & 6.452 & 244 \\
\hline & Asia & - & 0.048 & -10.487 & 9.789 & 0.445 & 3.422 & -0.411 & 3.426 & 244 \\
\hline \multirow[t]{2}{*}{ Inv Size } & Large (L) & - & -0.013 & -4.075 & 2.590 & 0.004 & 1.150 & -0.460 & 3.487 & 244 \\
\hline & Middle/Small (M/S) & - & -0.088 & -6.635 & 7.898 & -0.067 & 1.430 & -0.296 & 9.248 & 244 \\
\hline \multirow[t]{8}{*}{ Inv Area/Size } & Global-L & - & -0.166 & -4.343 & 3.669 & -0.001 & 1.391 & -0.430 & 3.252 & 244 \\
\hline & North America-L & - & -0.006 & -2.083 & 2.374 & 0.008 & 0.531 & -0.005 & 5.426 & 244 \\
\hline & Europe-L & - & -0.092 & -9.899 & 4.932 & 0.070 & 2.004 & -1.031 & 6.544 & 244 \\
\hline & Asia-L & - & 0.025 & -9.950 & 10.519 & 0.468 & 3.435 & -0.276 & 3.180 & 244 \\
\hline & Global-M/S & - & 0.298 & -16.998 & 14.594 & 0.258 & 4.089 & 0.050 & 5.081 & 215 \\
\hline & North America-M/S & - & -0.100 & -3.500 & 3.087 & -0.079 & 0.865 & -0.548 & 5.364 & 244 \\
\hline & Europe-M/S & - & -0.015 & -5.016 & 7.451 & -0.138 & 1.742 & 0.544 & 4.887 & 244 \\
\hline & Asia-M/S & - & 0.246 & -12.311 & 9.413 & 0.399 & 3.725 & -0.459 & 3.673 & 130 \\
\hline
\end{tabular}

Legend: The Table reports average monthly returns $\left(\overline{R_{t}}\right)$, Sharpe Ratios $(\mathbf{S h R})$ and other descriptive statistics for SR Superfunds (Panel A), conventional Superfunds (Panel B) and Difference Superfunds (SRF-CF) (Panel C) in the matched sample. 
Table 4: Five factor model estimates for SR, Conventional, and Difference (SRF-CF) Superfunds - Matched Sample

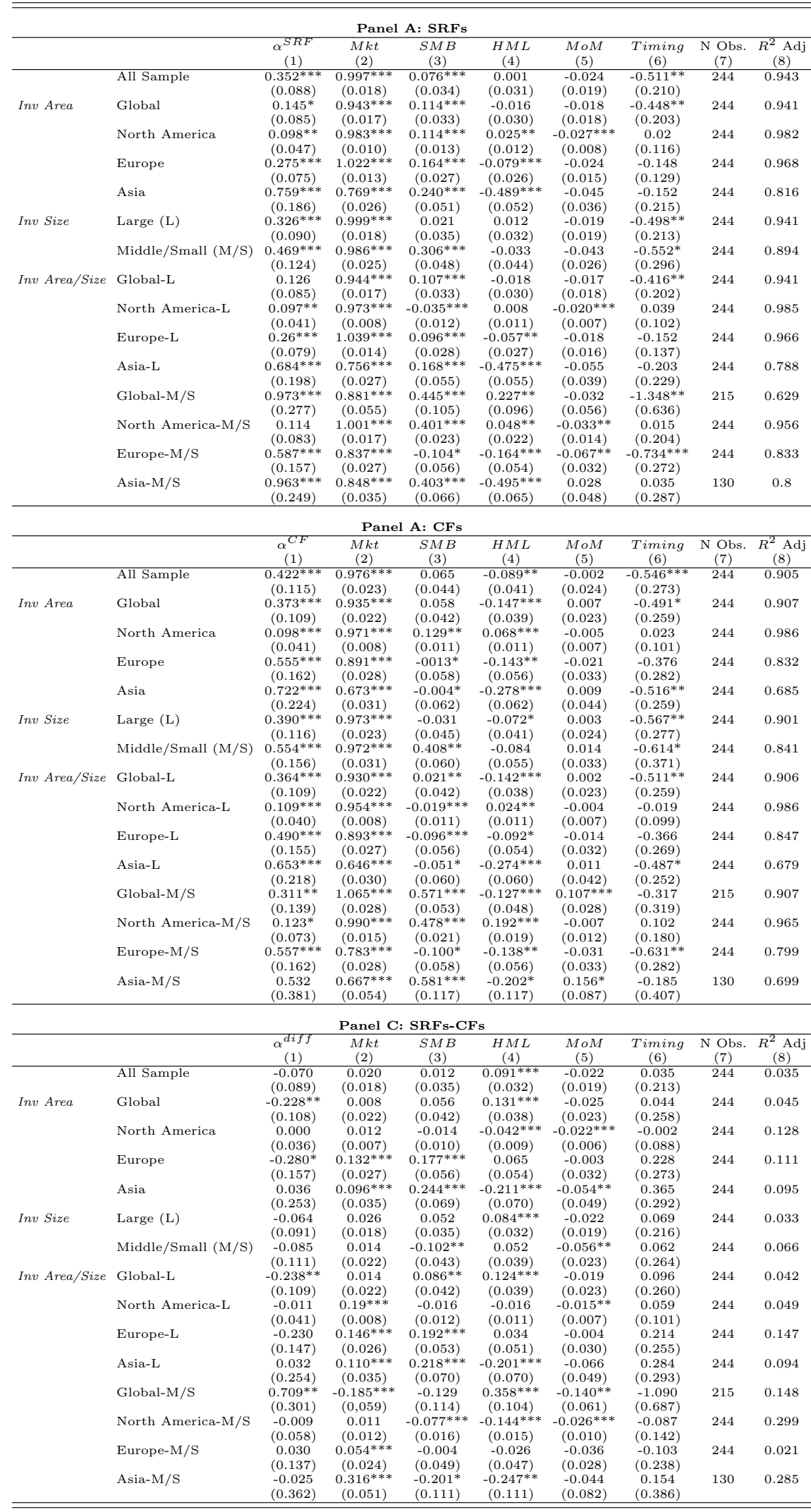

Legend: The Table reports estimate findings of the five factor model for SR Superfunds (Panel A), Conventional Superfunds (Panel B), and Difference Superfunds (SRF-CF) (Panel C) in the matched sample.

$\alpha$ is the Jensen alpha that captures fund manager contribution to financial performance; $M k t$ is the monthly return of the stock market index used as benchmark for each Investment Area/Sector specifications; $S M B$ (Small Minus $\mathrm{Big}$ ) is the factor capturing exposition to small size risk calculated as the difference in returns between a small cap and a large cap portfolio at the same time t; HML (High Minus Low) is the factor capturing exposition to bankruptcy risk calculated as the difference in returns between a portfolio of companies with high book-to-market and a portfolio of companies with low book-to-market at the same time t; $M o M$ is the momentum risk factor based on the difference in returns of a portfolio with stocks with the highest returns in the last market period (eleven months) against those of a portfolio of stocks with the lowest returns in the same market period; Timing is the timing risk factor calculated as the square of the return of the benchmark index.

* $p$-value $<0.05,{ }^{* *} p$-value $<0.01,{ }^{* * *} p$-value $<0.001$; (Robust Standard Errors). 
Table 5: Five factor model estimates for SR, Conventional, and Difference (SRF-CF) fund by fund - Matched Sample - Overall period

\begin{tabular}{|c|c|c|c|c|c|c|c|c|}
\hline \multicolumn{9}{|c|}{ Panel A: SRFs } \\
\hline & & $\begin{array}{c}\alpha^{\text {diff }} \\
(1)\end{array}$ & $\begin{array}{c}M k t \\
(2)\end{array}$ & $\begin{array}{c}S M B \\
(3)\end{array}$ & $\begin{array}{c}H M L \\
(4)\end{array}$ & $\begin{array}{c}M o M \\
(5)\end{array}$ & $\begin{array}{c}\text { Timing } \\
(6)\end{array}$ & $\begin{array}{c}\text { N Obs. } \\
(7)\end{array}$ \\
\hline & All Sample & $-0.152^{* * *}$ & $1.057^{* * *}$ & 0.006 & $-0.075^{* * *}$ & $-0.018^{* * *}$ & $-0.105^{* * *}$ & 1213 \\
\hline \multirow{4}{*}{ Inv Area } & Global & $-0.207^{* * *}$ & $1,008^{* * *}$ & $0.031 * *$ & $-0.152^{* * *}$ & $-0.009 * *$ & $-0.136^{* * *}$ & 417 \\
\hline & North America & $-0.269^{* * *}$ & $0.970^{* * *}$ & $0.132 * * *$ & $0.030 * * *$ & $-0.013^{* * *}$ & 0.033 & 336 \\
\hline & Europe & $-0.059 * * *$ & $1.007^{* * *}$ & $0.085 * * *$ & $-0.039 * * *$ & $-0.026^{* * *}$ & $-0.097 * * *$ & 405 \\
\hline & Asia & $0.094^{*}$ & $0.968^{*}$ & -0.061 & $-0.472^{* * *}$ & $-0.074 * * *$ & 0.024 & 55 \\
\hline \multirow[t]{2}{*}{ Inv Size } & Large $(\mathrm{L})$ & $-0.173^{* * *}$ & $1.062 * * *$ & $-0.071 * * *$ & $-0.082^{* * *}$ & $-0.019 * * *$ & $-0.124 * * *$ & 1019 \\
\hline & Middle/Śmall (M/S) & -0.037 & $1.029 * * *$ & $0.376^{* * *}$ & -0.047 & $-0.019^{*}$ & $-0.139 * *$ & 194 \\
\hline \multirow[t]{8}{*}{ Inv Area/Size } & Global-L & $-0.210^{* * *}$ & $1.005^{* * *}$ & 0.016 & $-0.145^{* * *}$ & $-0.008^{*}$ & $-0.136 * * *$ & 403 \\
\hline & North America-L & $-0.227^{* * *}$ & $0.965^{* * *}$ & $-0.053^{* * *}$ & 0.004 & $-0.022 * * *$ & 0.007 & 212 \\
\hline & Europe-L & $-0.066^{* * *}$ & $1.016^{* * *}$ & 0.005 & -0.018 & $-0.023^{* * *}$ & $-0.105^{* * *}$ & 354 \\
\hline & Asia-L & 0.069 & $0.969 * * *$ & $-0.109 * *$ & $-0.467 * * *$ & $-0.086^{*}$ & 0.029 & 50 \\
\hline & Global-M/S & -0.249 & $0.943^{* * *}$ & $0.228^{* * *}$ & $0.255^{*}$ & -0.058 & -0.272 & 14 \\
\hline & North America-M/S & $-0.341 * * *$ & $0.984 * * *$ & $0.483^{* * *}$ & $0.075^{* *}$ & 0.007 & 0.074 & 124 \\
\hline & Europe-M/S & $0.140^{*}$ & $0.826^{* * *}$ & -0.022 & $-0.091 * *$ & $-0.038 * * *$ & $-0.442^{* * *}$ & 51 \\
\hline & Asia-M/ & $0.351^{* * *}$ & $0.949^{* * *}$ & $0.412^{* * *}$ & $-0.522 * * *$ & $0.053^{*}$ & $-0.020^{*}$ & 5 \\
\hline \multicolumn{9}{|c|}{ Panel B: CFs } \\
\hline & & $\begin{array}{c}\alpha^{\text {diff }} \\
(1)\end{array}$ & $\begin{array}{c}M k t \\
(2)\end{array}$ & $\begin{array}{c}S M B \\
(3)\end{array}$ & $\begin{array}{c}H M L \\
(4)\end{array}$ & $\begin{array}{c}M o M \\
(5)\end{array}$ & $\begin{array}{c}\text { Timing } \\
(6)\end{array}$ & $\begin{array}{c}\text { N Obs. } \\
(7)\end{array}$ \\
\hline \multirow{5}{*}{ Inv Area } & All Sample & $-0.099^{* * *}$ & $1.025^{* * *}$ & 0.012 & $-0.076^{* * *}$ & -0.010 & $-0.106^{* * *}$ & 1213 \\
\hline & Global & $-0,140 * * *$ & $0,968 * * *$ & $0.027^{* *}$ & $-0.162 * * *$ & -0.003 & $-0.138 * * *$ & 417 \\
\hline & North America & $-0.221 * * *$ & $0.976 * * *$ & $0.131 * * *$ & $0.035 * * *$ & -0.006 & 0.032 & 336 \\
\hline & Europe & 0.031 & $0.885^{* * *}$ & $0.088^{* * *}$ & $-0.054 * * *$ & $-0.032 * * *$ & $-0.094 * * *$ & 405 \\
\hline & Asia & $-0.235^{* * *}$ & $0.695^{* * *}$ & $-0.154 * * *$ & $-0.285^{* * *}$ & 0.019 & -0.017 & 55 \\
\hline \multirow[t]{2}{*}{ Inv Size } & Large $(\mathrm{L})$ & $-0.146^{* * *}$ & $1.023 * * *$ & $-0.068 * * *$ & $-0.083^{* * *}$ & $-0.010 * * *$ & $-0.126 * * *$ & 1019 \\
\hline & e/Small (M/S) & $0.048^{*}$ & $1.011 * * *$ & $0.373^{* * *}$ & -0.036 & 0.005 & $-0.151 * *$ & 194 \\
\hline \multirow[t]{8}{*}{ Inv Area/Size } & Global-L & $-0.162^{* * *}$ & $0.964 * * *$ & 0.010 & $-0.155^{* * *}$ & -0.003 & $-0.138^{* * *}$ & 403 \\
\hline & North America-L & $-0.192^{* * *}$ & $0.963^{* * *}$ & $-0.054^{* * *}$ & 0.009 & $-0.013^{* * *}$ & 0.004 & 212 \\
\hline & Europe-L & -0.018 & $0.890^{* * *}$ & 0.000 & $-0.031 * * *$ & $-0.027^{* * *}$ & $-0.099 * * *$ & 354 \\
\hline & Asia-L & $-0.302^{* * *}$ & $0.680^{* * *}$ & $-0.262^{* * *}$ & $-0.291 * * *$ & 0.005 & -0.015 & 50 \\
\hline & Global-M/S & 0.190 & $0.973^{* * *}$ & $0.458^{* * *}$ & 0.128 & $-0.111^{*}$ & $-0.280 *$ & 14 \\
\hline & North America-M/S & $-0.185^{* * *}$ & $1.004 * * *$ & $0.506^{* * *}$ & $0.077^{* * *}$ & 0.002 & 0.080 & 124 \\
\hline & Europe-M/S & $0.201 * * *$ & $0.786^{* * *}$ & -0.052 & -0.079 & $-0.029 * *$ & $-0.437 * * *$ & 51 \\
\hline & Asia-M/S & 0.238 & $0.670 * * *$ & $0.426 * * *$ & $-0.265^{* * *}$ & $0.158^{* * *}$ & 0.032 & 5 \\
\hline \multicolumn{9}{|c|}{ Panel C: SRFs-CFs } \\
\hline & & $\begin{array}{c}\alpha^{\text {diff }} \\
(1)\end{array}$ & $\begin{array}{c}M k t \\
(2)\end{array}$ & $\begin{array}{c}S M B \\
(3)\end{array}$ & $\begin{array}{c}H M L \\
(4)\end{array}$ & $\begin{array}{c}M o M \\
(5)\end{array}$ & $\begin{array}{c}\text { Timing } \\
(6)\end{array}$ & $\begin{array}{c}\text { N Obs. } \\
(7)\end{array}$ \\
\hline \multirow{5}{*}{ Inv Area } & All Sample & $-0.052^{* * *}$ & $0.033^{* * *}$ & -0.005 & 0.002 & -0.008 & 0.001 & 1213 \\
\hline & Global & $-0.067^{* * *}$ & $0.040^{* * *}$ & 0.004 & 0.010 & -0.006 & 0.001 & 417 \\
\hline & North America & -0.048 & -0.006 & 0.001 & -0.005 & -0.007 & 0.001 & 336 \\
\hline & Europe & $-0.090^{* * *}$ & $0.122^{* * *}$ & -0.003 & 0.015 & 0.006 & -0.002 & 405 \\
\hline & Asia & $0.330 * * *$ & $0.273^{* *}$ & 0.092 & $-0.187^{* * *}$ & $-0.093^{* * *}$ & 0.041 & 55 \\
\hline \multirow[t]{2}{*}{ Inv Size } & Large $(\mathrm{L})$ & -0.028 & $0.039 * * *$ & -0.003 & 0.001 & $-0.009 * *$ & 0.003 & 1019 \\
\hline & Middle/Small (M/S) & $-0.085^{*}$ & 0.018 & 0.003 & -0.011 & $-0,023^{*}$ & 0.012 & 194 \\
\hline \multirow[t]{8}{*}{ Inv Area/Size } & Global-L & $-0.048^{* *}$ & $0.041 * * *$ & 0.006 & 0.010 & -0.006 & 0.002 & 403 \\
\hline & North America-L & -0.035 & 0.002 & 0.001 & -0.005 & -0.008 & 0.003 & 212 \\
\hline & Europe-L & $-0.048^{*}$ & $0.126 * * *$ & 0.005 & 0.014 & 0.004 & -0.006 & 354 \\
\hline & Asia-L & $0.370^{* * *}$ & $0.290 * * *$ & $0.153^{* *}$ & $-0.176^{* *}$ & $-0.093 * *$ & 0.043 & 50 \\
\hline & Global-M/S & 0.439 & -0.030 & $-0.230 * *$ & 0.126 & 0.053 & 0.008 & 14 \\
\hline & North America-M/S & $-0.156^{*}$ & -0.021 & -0.023 & -0.002 & 0.006 & -0.006 & 124 \\
\hline & Europe-M/S & -0.061 & 0.040 & 0.029 & -0.013 & -0.009 & -0.004 & 51 \\
\hline & Asia-M/S & 0.112 & $0.279 * * *$ & -0.015 & $-0.257^{* * *}$ & $-0.105^{*}$ & -0.053 & 5 \\
\hline
\end{tabular}

Legend: The Table reports estimate findings of the five factor model for the SR fund by fund (Panel A), the conventional fund by fund (Panel B), and the Difference (SRF-CF) fund by fund (Panel C) approach in the matched sample.

$\alpha$ is the Jensen alpha that captures fund manager contribution to financial performance; $M k t$ is the monthly return of the stock market index used as benchmark for each Investment Area/Sector specifications; $S M B$ (Small Minus Big) is the factor capturing exposition to small size risk calculated as the difference in returns between a small cap and a large cap portfolio at the same time t; $H M L$ (High Minus Low) is the factor capturing exposition to bankruptcy risk calculated as the difference in returns between a portfolio of companies with high book-to-market and a portfolio of companies with low book-to-market at the same time t; $M o M$ is the momentum risk factor based on the difference in returns of a portfolio with stocks with the highest returns in the last market period (eleven months) against those of a portfolio of stocks with the lowest returns in the same market period; Timing is the timing risk factor calculated as the square of the return of the benchmark index.

${ }^{*} p$-value $<0.05,{ }^{* *} p$-value $<0.01,{ }^{* * *} p$-value $<0.001$ 
Table 6: Five factor model estimates for SR, Conventional, and Difference (SRF-CF) fund by fund - Matched Sample - 2007 global financial crisis period

\begin{tabular}{|c|c|c|c|c|c|c|c|c|}
\hline \multicolumn{9}{|c|}{ Panel A: SRFs } \\
\hline & & $\begin{array}{c}\alpha^{\text {diff }} \\
(1)\end{array}$ & $\begin{array}{c}M k t \\
(2)\end{array}$ & $\begin{array}{c}S M B \\
(3)\end{array}$ & $\begin{array}{c}H M L \\
(4)\end{array}$ & $\begin{array}{c}M o M \\
(5)\end{array}$ & $\begin{array}{c}\text { Timing } \\
(6)\end{array}$ & $\begin{array}{r}\text { N Obs. } \\
(7) \\
\end{array}$ \\
\hline \multirow{5}{*}{ Inv Area } & All Sample & $0.165^{* * *}$ & $1.055^{* * *}$ & $0.126^{* * *}$ & $-0.125^{* * *}$ & $-0.030^{* * *}$ & $-0.298^{* * *}$ & 970 \\
\hline & Global & $0.117^{* *}$ & $1.046^{* * *}$ & $0.143^{* * *}$ & $-0.168^{* * *}$ & 0.018 & $-0.323^{* * *}$ & 333 \\
\hline & North America & $-0.117^{* * *}$ & $0.973^{* * *}$ & $0.179 * * *$ & -0.012 & $-0.038^{* * *}$ & $-0.210^{* *}$ & 263 \\
\hline & Europe & $0.153^{* * *}$ & $0.993^{* * *}$ & $0.161 * * *$ & $-0.187^{* * *}$ & $-0.075^{* * *}$ & $-0.269^{* * *}$ & 330 \\
\hline & Asia & $-0.302 * * *$ & $0,963 * * *$ & $-0.103 * *$ & $-0.421 * * *$ & $-0.097 * * *$ & -0.065 & 44 \\
\hline \multirow[t]{2}{*}{ Inv Size } & Large $(\mathrm{L})$ & $0.158^{* * *}$ & $1.071^{* * *}$ & $0.058 * * *$ & $-0.120^{* * *}$ & -0.006 & $-0.262^{* * *}$ & 805 \\
\hline & Middle/Small (M/S) & $0.196^{* * *}$ & $0.978^{* * *}$ & $0.456^{* * *}$ & $-0.149^{* * *}$ & $-0.145^{* * *}$ & $-0.472^{* * *}$ & 165 \\
\hline \multirow[t]{10}{*}{ Inv Area/Size } & Global-L & $0.102 *$ & $1.038^{* * *}$ & $0.119^{* * *}$ & $-0.153^{* * *}$ & 0.017 & $-0.335^{* * *}$ & 319 \\
\hline & North America-L & $-0.165^{* * *}$ & $0.971^{* * *}$ & $-0.029 * * *$ & 0.021 & $-0.030^{* * *}$ & $-0.122 *$ & 163 \\
\hline & Europe-L & $0.168^{* * *}$ & $1.015^{* * *}$ & $0.052 * *$ & $-0.219 * * *$ & $-0.071^{* * *}$ & $-0.271^{* * *}$ & 284 \\
\hline & Asia-L & $-0.350 * * *$ & $0.956^{* * *}$ & $-0.165^{* * *}$ & $-0.421 * * *$ & $-0.108 * * *$ & $-0.107 * * *$ & 39 \\
\hline & Global-M/S & 0.027 & $0.922^{* * *}$ & $0.361 * * *$ & 0.293 & $-0.309^{* *}$ & 0.259 & \\
\hline & North America-M/S & -0.038 & $0.975 * * *$ & $0.518^{* * *}$ & -0.065 & $-0.050 * * *$ & $-0.354 * * *$ & 100 \\
\hline & Europe-M/S & 0.209 & $0.847^{* * *}$ & $0.123 * * *$ & 0.030 & $-0.104^{* * *}$ & $-0.803^{* * *}$ & 33 \\
\hline & Asia-M/S & 0.076 & $1.013^{* * *}$ & $0.382^{* * *}$ & $-0.421 * *$ & -0.013 & $0.259 * * *$ & 5 \\
\hline & & \multicolumn{3}{|c|}{ Panel B: CFs } & & & & \\
\hline & & $\begin{array}{c}\alpha^{\text {diff }} \\
(1)\end{array}$ & $\begin{array}{c}M k t \\
(2)\end{array}$ & $\begin{array}{c}S M B \\
(3)\end{array}$ & $\begin{array}{c}H M L \\
(4)\end{array}$ & $\begin{array}{c}M o M \\
(5)\end{array}$ & $\begin{array}{c}\text { Timing } \\
(6)\end{array}$ & $\begin{array}{r}\text { N Obs. } \\
(7) \\
\end{array}$ \\
\hline \multirow{5}{*}{ Inv Area } & All Sample & -0.015 & $1.007^{* * *}$ & $0.116^{* * *}$ & $-0.123^{* * *}$ & $-0.037^{* * *}$ & $-0.287^{* * *}$ & 970 \\
\hline & Global & -0.019 & $0.983^{* * *}$ & $0.114^{* * *}$ & $-0.169 * * *$ & 0.007 & $-0.299 * * *$ & 333 \\
\hline & North America & $-0.112^{* * *}$ & $0.973^{* * *}$ & $0.171 * * *$ & -0.004 & $-0.029 * * *$ & $-0.203^{* *}$ & 263 \\
\hline & Europe & $-0.111^{* * *}$ & $0.875^{* * *}$ & $0.146^{* * *}$ & $-0.202^{* * *}$ & $-0.082^{* * *}$ & $-0.235^{* * *}$ & 330 \\
\hline & Asia & $-0.820 * * *$ & $0.729^{* * *}$ & $-0.181^{* * *}$ & $-0.308^{* * *}$ & $-0.067 * * *$ & $-0.113^{* *}$ & 44 \\
\hline \multirow[t]{2}{*}{ Inv Size } & Large $(\mathrm{L})$ & -0.042 & $1.012^{* * *}$ & $0.035 * * *$ & $-0.122^{* * *}$ & -0.011 & $-0.248^{* * *}$ & 805 \\
\hline & Middle/Small (M/S) & $0.076^{* * *}$ & $0.975 * * *$ & $0.443 * * *$ & $-0.154 * * *$ & $-0,131^{* * *}$ & $-0,441 * * *$ & 165 \\
\hline \multirow[t]{10}{*}{ Inv Area/Size } & Global-L & 0.006 & $0.971 * * *$ & $0.077^{* * *}$ & $-0.160^{* * *}$ & 0.001 & $-0.316^{* * *}$ & 319 \\
\hline & North America-L & $-0.158 * * *$ & $0.966^{* * *}$ & $-0.030 * *$ & 0.023 & $-0.022 * * *$ & $-0.127^{*}$ & 163 \\
\hline & Europe-L & $-0.152^{* * *}$ & $0.884^{* * *}$ & 0.023 & $-0.238^{* * *}$ & $-0.083^{* * *}$ & $-0.247 * * *$ & 284 \\
\hline & Asia-L & $-0.981 * * *$ & $0.729^{* * *}$ & $-0.305^{* * *}$ & $-0.295^{* * *}$ & $-0.060 * *$ & $-0.113^{* *}$ & 39 \\
\hline & Global-M/S & -0.116 & $0.953^{* * *}$ & $0.373 * * *$ & 0.256 & $-0.298 * * *$ & $0.298^{*}$ & \\
\hline & North America-M/S & -0.022 & $0.999 * * *$ & $0.527 * * *$ & -0.049 & -0.027 & $-0.328^{*}$ & 100 \\
\hline & Europe-M/S & $-0.174 * *$ & $0.742^{* * *}$ & 0.032 & 0.067 & $-0.111 * * *$ & $-0.771 * *$ & 33 \\
\hline & Asia-M/S & -0.311 & $0.657^{* * *}$ & 0.313 & -0.142 & 0.038 & 0.108 & 5 \\
\hline & & \multicolumn{3}{|c|}{ Panel C: SRFs-CFs } & & & & \\
\hline & & $\begin{array}{c}\alpha^{\text {diff }} \\
(1)\end{array}$ & $\begin{array}{c}M k t \\
(2)\end{array}$ & $\begin{array}{c}S M B \\
(3)\end{array}$ & $\begin{array}{c}H M L \\
(4)\end{array}$ & $\begin{array}{c}M o M \\
(5)\end{array}$ & $\begin{array}{c}\text { Timing } \\
(6)\end{array}$ & $\begin{array}{r}\text { N Obs. } \\
(7)\end{array}$ \\
\hline \multirow{5}{*}{ Inv Area } & All Sample & $0.179^{* * *}$ & $0.048^{* * *}$ & 0.010 & -0.002 & 0.007 & -0.011 & 970 \\
\hline & Global & $0.137^{* * *}$ & $0.063 * * *$ & 0.029 & 0.001 & 0.011 & -0.023 & 333 \\
\hline & North America & -0.005 & 0.000 & 0.008 & -0.008 & -0.009 & & 263 \\
\hline & Europe & $0.264 * * *$ & $0.119 * * *$ & 0.015 & 0.014 & 0.007 & -0.035 & 330 \\
\hline & Asia & $0.518^{* * *}$ & $0.234^{* * *}$ & 0.078 & -0.113 & -0.030 & 0.048 & 44 \\
\hline \multirow[t]{2}{*}{ Inv Size } & Large $(\mathrm{L})$ & $0.200^{* * *}$ & $0.059 * * *$ & 0.023 & 0.002 & 0.005 & -0.014 & 805 \\
\hline & Middle/Small (M/S) & $0.119^{*}$ & 0.003 & 0.013 & 0.005 & -0.014 & -0.031 & 165 \\
\hline \multirow[t]{8}{*}{ Inv Area/Size } & Global-L & 0.096 & $0.067 * * *$ & 0.042 & 0.008 & 0.017 & -0.019 & 319 \\
\hline & North America-L & -0.007 & 0.005 & 0.001 & -0.002 & -0.008 & 0.006 & 163 \\
\hline & Europe-L & $0.320^{* * *}$ & $0.131^{* * *}$ & 0.029 & 0.019 & 0.012 & -0.023 & 284 \\
\hline & Asia-L & $0.630^{* * *}$ & $0.227 * * *$ & $0.139^{* * *}$ & -0.126 & -0.048 & 0.006 & 39 \\
\hline & Global-M/S & 0.143 & -0.031 & -0.011 & 0.037 & -0.011 & -0.038 & \\
\hline & North America-M/S & -0.017 & -0.024 & -0.008 & -0.016 & -0.023 & -0.026 & 100 \\
\hline & Europe-M/S & $0.383^{* *}$ & $0.105^{*}$ & 0.091 & -0.037 & 0.006 & -0.032 & 33 \\
\hline & Asia-M/S & 0.387 & $0.356 *$ & 0.069 & $-0.279 * * *$ & -0.051 & 0.151 & 5 \\
\hline
\end{tabular}

Legend: The Table reports estimates of the five factor model for the SR fund by fund (Panel A), the conventional fund by fund (Panel B), and the Difference (SRF-CF) fund by fund (Panel C) approaches in the matched sample during the 2007 global financial crisis period.

$\alpha$ is the Jensen alpha that captures fund manager contribution to financial performance; $M k t$ is the monthly return of the stock market index used as benchmark for each Investment Area/Sector specifications; $S M B$ (Small Minus Big) is the factor capturing exposition to small size risk calculated as the difference in returns between a small cap and a large cap portfolio at the same time t; $H M L$ (High Minus Low) is the factor capturing exposition to bankruptcy risk calculated as the difference in returns between a portfolio of companies with high book-to-market and a portfolio of companies with low book-to-market at the same time t; $M o M$ is the momentum risk factor based on the difference in returns of a portfolio with stocks with the highest returns in the last market period (eleven months) against those of a portfolio of stocks with the lowest returns in the same market period; Timing is the timing risk factor calculated as the square of the return of the benchmark index.

${ }^{*} p$-value $<0.05,{ }^{* *} p$-value $<0.01,{ }^{* * *} p$-value $<0.001$ 